Article

\title{
Synthesis of Photoresponsive Dual NIR Two-Photon Absorptive [60]Fullerene Triads and Tetrads
}

\author{
Seaho Jeon ${ }^{1}$, Min Wang ${ }^{1}$, Loon-Seng Tan ${ }^{2}$, Thomas Cooper ${ }^{2}$, Michael R. Hamblin ${ }^{3,4}$ and \\ Long Y. Chiang ${ }^{1}$ *
}

1 Department of Chemistry, Institute of Nanoscience and Engineering Technology, University of Massachusetts, Lowell, MA 01854, USA

2 AFRL/RXAS, Functional Materials Division, Air Force Research Laboratory, Wright-Patterson Air Force Base, Dayton, OH 45433, USA

3 Wellman Center for Photomedicine, Massachusetts General Hospital, Department of Dermatology, Harvard Medical School, Boston, MA 02114, USA

4 Harvard MIT Division of Health Science and Technology, Cambridge, MA 02139, USA

* Authors to whom correspondence should be addressed; E-Mail: Long_Chiang@uml.edu; Tel.: +1-978-934-3663.

Received: 18 June 2013; in revised form: 30 July 2013 / Accepted: 5 August 2013 /

Published: 12 August 2013

\begin{abstract}
Broadband nonlinear optical (NLO) organic nanostructures exhibiting both ultrafast photoresponse and a large cross-section of two-photon absorption throughout a wide NIR spectrum may make them suitable for use as nonlinear biophotonic materials. We report here the synthesis and characterization of two $\mathrm{C}_{60}-(\text { antenna) })_{\mathrm{x}}$ analogous compounds as branched triad $\mathrm{C}_{60}\left(>\mathrm{DPAF}-\mathrm{C}_{18}\right)\left(>\mathrm{CPAF}-\mathrm{C}_{2 \mathrm{M}}\right)$ and tetrad $\mathrm{C}_{60}\left(>\mathrm{DPAF}-\mathrm{C}_{18}\right)\left(>\mathrm{CPAF}-\mathrm{C}_{2 \mathrm{M}}\right)_{2}$ nanostructures. These compounds showed approximately equal extinction coefficients of optical absorption over 400-550 $\mathrm{nm}$ that corresponds to near-IR two-photon based excitation wavelengths at 780-1,100 nm. Accordingly, they may be utilized as potential precursor candidates to the active-core structures of photosensitizing nanodrugs for $2 \gamma$-PDT in the biological optical window of $800-1,050 \mathrm{~nm}$.
\end{abstract}

Keywords: $\mathrm{C}_{60}-(\text { antenna })_{\mathrm{x}}$ nanostructures; ultrafast intramolecular energy-transfer; NIR two-photon absorption; $2 \gamma$-photodynamic therapeutic agent; photosensitizer 


\section{Introduction}

Fullerenes are nanocarbon cages with all $\mathrm{sp}^{2}$ carbons interlinked in a structure of hollow sphere. Highly strained curving regions of the cage surface consist of chemically reactive six fulvalenyl bridging olefins that can be utilized for making nucleophilic addition reactions. Chemical modification of $\mathrm{C}_{60}$ on only a limit number of functionalization sites may not lead to much alternation of the cage's photophysical properties. Conversely, nucleophilic addition of one or two light-harvesting antenna chromophores will largely enhance the cage's ability to respond and perform various photoinduced electronic and energy-related events by acting as an electron-acceptor [1,2]. The development of broadband nonlinear optical (NLO) organic nanostructures exhibiting both ultrafast photo-response and high efficiency in two-photon absorption throughout a wide NIR spectrum to variable laser pulses with duration ranging from fs to ns remains as the focus of nonlinear biophotonic materials. The goal requires the design of sophisticated, hydrophilic and biocompatible multifunctional NLO materials for two-photon absorption (2PA) based photodynamic therapy (2 $\gamma$-PDT) [3-7] against pathogens and cancer to minimize the damage to surrounding normal tissue. Photoresponsive complex fullerene derivatives [8-15] and a number of organic chromophores [16-19] have been found to exhibit enhanced nonlinear photonic behavior. The control of photodynamic effect is precise due to the fact that $2 \gamma$-PDT can only be practiced at the focal area of the laser beam that prevents side-effects arising from the undesirable photokilling of normal cells.

The most abundant [60]fullerene is more readily available commercially in up to kilogram quantities than a number of higher fullerenes. However, its visible absorption extinction coefficient is rather low. This limitation can be overcome by attaching highly fluorescent chromophores as light-harvesting antenna units, such as porphyrin [20,21] or dialkyldiphenylaminofluorene (DPAF- $\mathrm{C}_{\mathrm{n}}$ ), to enhance visible absorption of the resulting conjugates and, in the latter cases, 2PA cross-sections in the NIR wavelengths $[10,13,14]$. The absorbed photoenergy by the donor antenna was able to undergo efficient intramolecular transfer to the fullerene acceptor moiety, leading to the generation of excited triplet cage state ${ }^{3}\left(\mathrm{C}_{60}>\right)^{*}$ after the intersystem crossing from its excited singlet state ${ }^{1}\left(\mathrm{C}_{60}>\right)^{*}$. Triplet energy transfer from ${ }^{3}\left(\mathrm{C}_{60}>\right)^{*}$ to molecular oxygen produces singlet oxygen $\left({ }^{1} \mathrm{O}_{2}\right)$ that gives the cytotoxic effect to the cells in the Type-II photochemistry [22,23]. In this paper, we report the synthesis and spectroscopic characterization of photoresponsive dual NIR two-photon absorptive [60]fullerene triads and tetrads using the extended synthetic method for the preparation of their corresponding monoadduct analogous $\mathrm{C}_{60}\left(>\mathrm{DPAF}-\mathrm{C}_{18}\right) \mathbf{1}$ and $\mathrm{C}_{60}\left(>\mathrm{CPAF}-\mathrm{C}_{2 \mathrm{M}}\right) \mathbf{2}$, as shown in Scheme 1. These triads and tetrads are capable of undergoing 2PA-based photoexcitation process at either 780 or $980 \mathrm{~nm}$ making them potential precursor candidates to the active-core structures of nanodrugs for $2 \gamma$-PDT.

\section{Results and Discussion}

Structural design of hybrid [60]fullerene triads and tetrads was based on both linear and nonlinear optical characteristics of 9,9-dioctadecyl-2-diphenylaminofluorenyl-61-carbonylmethano[60]fullerene (1), $\mathrm{C}_{60}\left(>\mathrm{DPAF}_{18}\right.$ ) [24], and 9,9-di(2-methoxyethyl)-2-diphenylaminofluorenyl-61-(1,1-dicyanoethylenyl)methano[60]fullerene (2), $\mathrm{C}_{60}\left(>\mathrm{CPAF}-\mathrm{C}_{2 \mathrm{M}}\right)$ [25], to construct an unique nanostructure 
system with a shared $\mathrm{C}_{60}$ cage. Specifically, covalent attachment of an antenna donor chromophore to a $\mathrm{C}_{60}$ molecule (electron-acceptor) was accomplished via a periconjugation linkage with a physical separation distance of only $<3.5 \AA$ between the donor and acceptor moieties. This led to the realization of ultrafast intramolecular energy- and/or electron-transfer from photoexcited antenna moiety to $\mathrm{C}_{60}$ in $<130-150$ fs [14] that made this type of $\mathrm{C}_{60}$-antenna conjugates, $\mathrm{C}_{60}\left(>\text { DPAF- } \mathrm{C}_{\mathrm{n}}\right)_{\mathrm{x}}$, capable of exhibiting photoresponse in a nearly instantaneous time scale to protect against high-intensity radiation. By increasing the number of attached antennae to four per $\mathrm{C}_{60}$ cage giving starburst pentad nanostructures, highly enhanced fs $2 \mathrm{PA}$ cross-section values were observed in a concentration-dependent manner [26]. Upon the chemical alteration of the keto group of $\mathrm{C}_{60}\left(>\mathrm{DPAF}-\mathrm{C}_{\mathrm{n}}\right)$ bridging between $\mathrm{C}_{60}$ and the antenna moiety to a highly electron-withdrawing 1,1-dicyanoethylenyl (DCE) group, it was possible to extend the $\pi$-conjugation in the resulting $\mathrm{C}_{60}\left(>\mathrm{CPAF}-\mathrm{C}_{\mathrm{n}}\right)$ analogous chromophore molecules to a close contact with the cage current. This led to a large bathochromic shift of the linear optical absorption of $\mathrm{C}_{60}\left(>\mathrm{CPAF}-\mathrm{C}_{2}\right)$ moving from $410 \mathrm{~nm}\left(\lambda_{\max }\right)$ of the parent keto-compound to $503 \mathrm{~nm}$ with the shoulder band being extended beyond $550 \mathrm{~nm}$ in the UV-vis spectrum. The shift considerably increased its light-harvesting ability in visible wavelengths and caused a nearly 6-fold higher in the production quantum yield of singlet oxygen $\left({ }^{1} \mathrm{O}_{2}\right)$ from $\mathrm{C}_{60}\left(>\mathrm{CPAF}-\mathrm{C}_{2 \mathrm{M}}\right)$ as compared with that of $\mathrm{C}_{60}\left(>\mathrm{DPAF}-\mathrm{C}_{2 \mathrm{M}}\right)$. The mechanism of ${ }^{1} \mathrm{O}_{2}$ production was originated from the intermolecular triplet-energy transfer from the ${ }^{3}\left(\mathrm{C}_{60}>\right)^{*}$ cage moiety to ${ }^{3} \mathrm{O}_{2}$. A large increase in the production of reactive oxygen species (ROS) by excited $\mathrm{C}_{60}\left(>\mathrm{CPAF}-\mathrm{C}_{2 \mathrm{M}}\right)$ explained its effective photokilling of HeLa cells in vitro, via $1 \gamma$-PDT [25]. The observation demonstrated the intramolecular/intramolecular interaction between the excited CPAF- $\mathrm{C}_{\mathrm{n}}$ donor antenna moiety and the acceptor $\mathrm{C}_{60}$ cage that was also confirmed by transient absorption spectroscopic measurements using $\mathrm{ns}$ laser pulses at 480-500 $\mathrm{nm}$ [27]. The behavior resembles that of DPAF- $\mathrm{C}_{\mathrm{n}}$ antenna with transient photoexcitation at 380-410 $\mathrm{nm}$ reported previously [28]. By extending the same intramolecular photophysical properties to 2PA-based excitation applications, these $\mathrm{C}_{60}$-(antenna) $)_{\mathrm{x}}$ analogous nanostructures may be utilized as potential photosensitizers for $2 \gamma$-PDT at either $800 \mathrm{~nm}$ (with DPAF antenna) or $1,000 \mathrm{~nm}$ (with CPAF antenna) that is well-suited to the biological optical window of 800-1,100 nm.

Accordingly, selective attachment of these two antenna moiety types DPAF- $C_{n}$ and CPAF-C $C_{n}$ in combination as hybrid chromophore addends to a single $\mathrm{C}_{60}$ cage should result in the formation of new methano[60]fullerene triads, $\mathrm{C}_{60}\left(>\mathrm{DPAF}_{-} \mathrm{C}_{18}\right)\left(>\mathrm{CPAF}-\mathrm{C}_{2 \mathrm{M}}\right) \mathbf{3}$, and tetrads, $\mathrm{C}_{60}\left(>\mathrm{DPAF}-\mathrm{C}_{18}\right)\left(>\mathrm{CPAF}-\mathrm{C}_{2 \mathrm{M}}\right)_{2}$ $\mathbf{4}$, as shown in Scheme 1. The core chromophore moiety of $\mathbf{3}$ and $\mathbf{4}$ will then be capable of performing dual-band $2 \gamma$-PDT-based photoinduced biocidal effects with enhanced penetration depth at 800-1,100 nm. Synthetically, preparation of $\mathbf{3}$ and $\mathbf{4}$ was accomplished by the synthesis of a structurally well-defined monoadduct $\mathbf{1}$, followed by the attachment of one or two CPAF- $\mathrm{C}_{2 \mathrm{M}}$ antenna in sequence. A key intermediate precursor, 7- $\alpha$-bromoacetyl-9,9-dioctadecyl-2-diphenylaminofluorene $\left(\right.$ BrDPAF- $\left.\mathrm{C}_{18}, 8\right)$ was prepared by a three-step reaction involving first palladium catalyzed diphenylamination of commercially available 2-bromofluorene at the $\mathrm{C} 2$ position of the fluorene ring to afford DPAF 5 (Scheme1). It was followed by dialkylation at the C9 carbon position of 5 using 1-bromooctadecane as the reagent in the presence of potassium $t$-butoxide, as a base, in THF at $0-25{ }^{\circ} \mathrm{C}$ to give the corresponding 9,9-dioctadecyl-2-diphenylaminofluorene (DPAF-C $\left.{ }_{18}\right)$ in $97 \%$ yield. Friedel-Crafts acylation of DPAF- $\mathrm{C}_{18}$ with $\alpha$-bromoacetyl bromide and $\mathrm{AlCl}_{3}$ in $\mathrm{CH}_{2} \mathrm{Cl}-\mathrm{CH}_{2} \mathrm{Cl}$ 
at $0{ }^{\circ} \mathrm{C}$ for a period of $4.0 \mathrm{~h}$ afforded the compound $\mathbf{8}$ in a yield of $96 \%$. Addition reaction of $\mathbf{8}$ to $\mathrm{C}_{60}$ was carried out in the presence of 1,8-diazabicyclo[5.4.0]undec-7-ene (DBU, 1.0 eq.) at ambient temperature for $4.0 \mathrm{~h}$ to result in $\mathrm{C}_{60}\left(>\mathrm{DPAF}-\mathrm{C}_{18}\right) \mathbf{1}$ in $65 \%$ yield (based on recovered residual $\mathrm{C}_{60}$ ) after column chromatographic purification.

Scheme 1. Synthesis of 3 and $\mathbf{4}$.
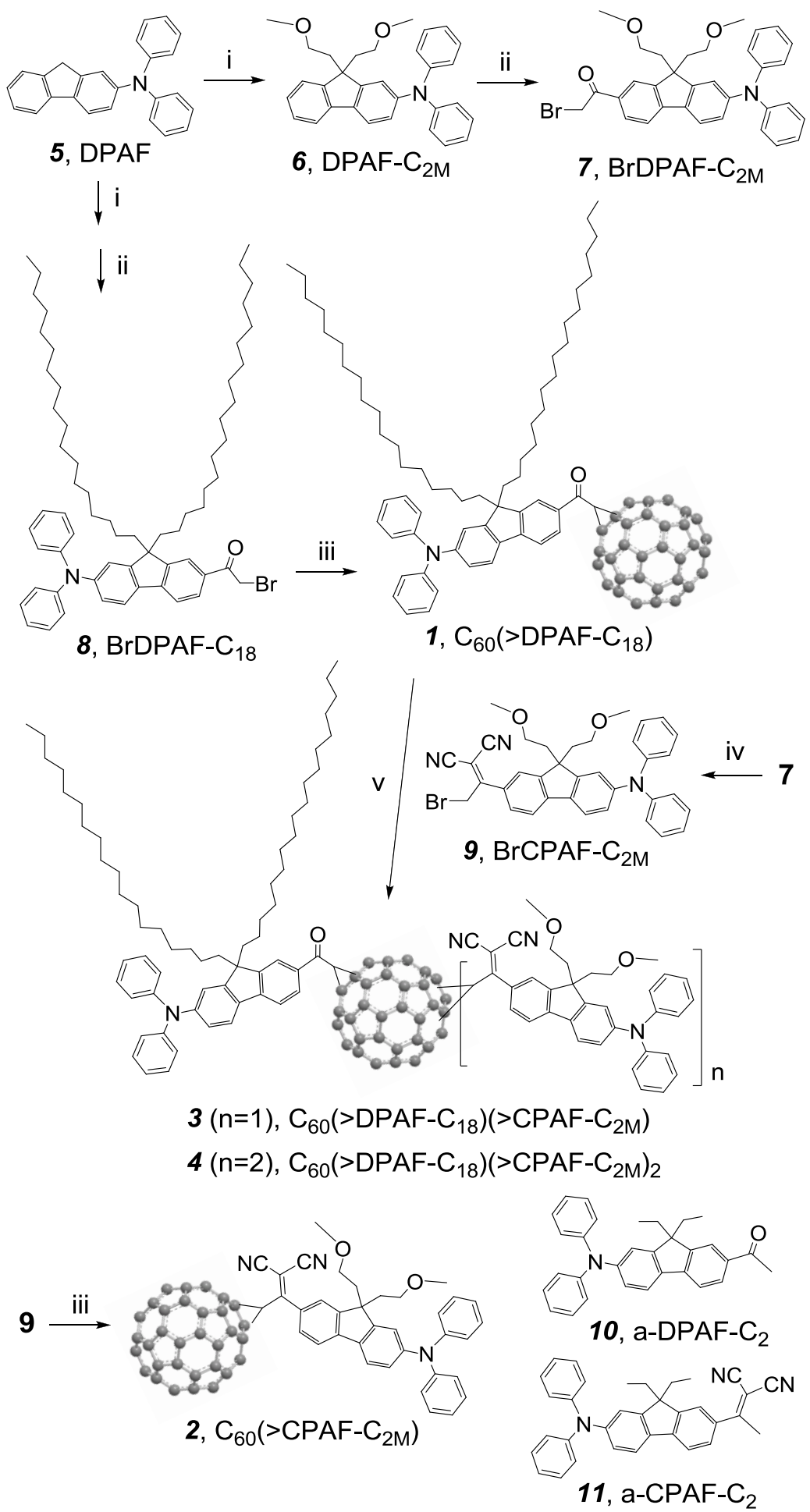

Reagents and conditions: (i) 2- $\mathrm{MeOCH}_{2} \mathrm{CH}_{2}-\mathrm{OMs}$ (for 6), $1-\mathrm{C}_{18} \mathrm{H}_{37} \mathrm{Br}$ (for 8), $t$-BuOK in THF, $0{ }^{\circ} \mathrm{C}-$ r.t., $4 \mathrm{~h}$; (ii) $\alpha$-bromoacetyl bromide, $\mathrm{AlCl}_{3}, \mathrm{ClCH}_{2} \mathrm{CH}_{2} \mathrm{Cl}, 0{ }^{\circ} \mathrm{C}$, $4 \mathrm{~h}$; (iii) $\mathrm{DBU}$, toluene, r.t., $4 \mathrm{~h}$; (iv) $\mathrm{TiCl}_{4}$, pyridine, $\mathrm{CH}_{2}(\mathrm{CN})_{2}, \mathrm{CHCl}_{3}$, r.t., $5.0 \mathrm{~min}$; (v) DBU, toluene, r.t., 4 h. 
A similar reaction sequence was applied for the synthesis of the compound 2 by replacing two octadecyl groups with 2-methoxyethyl groups. Thus, 2-methoxyethyl methanesulfonate was used as a leaving group for dialkylation of DPAF 5 followed by Friedel-Crafts acylation with $\alpha$-bromoacetyl bromide and $\mathrm{AlCl}_{3}$ to yield 7- $\alpha$-bromoacetyl-9,9-di(2-methoxy)ethyl-2-diphenylaminofluorene (BrDPAF- $\left.\mathrm{C}_{2 \mathrm{M}}, 7\right)$, Subsequent conversion of the keto group of 7 to the corresponding 1,1-dicyanoethylenyl (DCE) group was carried out by the reaction using malononitrile as a reagent, pyridine as a base, and titanium tetrachloride as a deoxygenation agent in dry chloroform at ambient temperature for a short period of $5.0 \mathrm{~min}$. The reaction resulted in the corresponding diphenylaminofluorene BrCPAF- $\mathrm{C}_{2 \mathrm{M}} 9$ in a yield of $89 \%$ after chromatographic purification (PTLC, $\mathrm{SiO}_{2}, \mathrm{CHCl}_{3}$ as the eluent). Attachment of a $\mathrm{CPAF}-\mathrm{C}_{2 \mathrm{M}}$ antenna arm to a $\mathrm{C}_{60}$ cage was carried out by identical reaction conditions as those for 1 with DBU (1.0 eq.) at room temperature for $4.0 \mathrm{~h}$ to afford 7-(1,2-dihydro1,2-methano[60]fullerene-61-\{1,1-dicyanoethylenyl $\}$ )-9,9-di(2-methoxyethyl)-2-diphenylaminofluorene $\mathrm{C}_{60}\left(>\mathrm{CPAF}-\mathrm{C}_{2 \mathrm{M}}\right), 2$ ) as orange red solids in $53 \%$ yield (based on recovered $\mathrm{C}_{60}$ ). The bulkiness of DPAF- $\mathrm{C}_{18}$ and $\mathrm{CPAF}-\mathrm{C}_{2 \mathrm{M}}$ in size can prevent these two types of antenna moieties form locating in close vicinity to each other at the cage surface. By considering the regio-location of reactive bicyclopentadienyl olefin bonds on the fullerene surface, when the first antenna is bound at the northpole location, the second antenna arm is most likely to be pushed away to the equator area of the $\mathrm{C}_{60}$ sphere. Therefore, only a very limited number of multiadduct regioisomers per $\mathrm{C}_{60}$ are likely to form. Indeed, by controlling the reaction kinetic rate with two molar equivalents of $\mathrm{CPAF}-\mathrm{C}_{2 \mathrm{M}}$ applied in the reaction with 1 in the presence of DBU (2.0 eq.), only two clear PTLC $\left(\mathrm{SiO}_{2}\right.$, toluene-ethyl acetate/9:1 as the eluent) bands in the product mixtures were observed in addition to the starting $1(\sim 15 \%)$. The first less polar product band at $R_{\mathrm{f}}=0.5$ was found to be the bisadduct $\mathrm{C}_{60}\left(>\mathrm{DPAF}-\mathrm{C}_{18}\right)\left(>\mathrm{CPAF}-\mathrm{C}_{2 \mathrm{M}}\right) 3$ isolated as orange-brown solids in $28 \%$ yield. The second more polar product band at $R_{\mathrm{f}}=0.4$ (toluene-ethyl acetate/4:1 as the eluent) was determined to be the trisadduct $\mathrm{C}_{60}\left(>\mathrm{DPAF}_{-\mathrm{C}_{18}}\right)\left(>\mathrm{CPAF}-\mathrm{C}_{2 \mathrm{M}}\right)_{2} 4$ isolated as red-brown solids in $40 \%$ yield.

Spectroscopic characterization of $\mathbf{1}$ and $\mathbf{2}$ was performed mainly by: (i) the clear detection of a group of molecular mass ion peaks with the maximum peak intensity centered at $\mathrm{m} / z, 1,600\left(\mathrm{MH}^{+}\right.$of $\left.\mathbf{1}\right)$ and 1,258 $\left(\mathrm{MH}^{+}\right.$of 2) (Supporting Information) using positive ion matrix-assisted laser desorption ionization (MALDI-TOF) mass spectroscopy and (ii) analyses of ${ }^{13} \mathrm{C}-\mathrm{NMR}$ spectra. The former spectra were also accompanied with two groups of fragmented mass ion peaks at $m / z 720$ and 734/735 corresponding to the mass units of $\mathrm{C}_{60}$ and $\mathrm{C}_{60}>$, respectively, indicating high stability of the fullerene cage under MALDI-MS conditions. In addition to the IR spectral analysis (Figure 1) of the carbonyl stretching vibration band at $1,674 \mathrm{~cm}^{-1}$ for $\mathbf{1}$ and the cyano $(-\mathrm{C} \equiv \mathrm{N})$ stretching band centered $2,224 \mathrm{~cm}^{-1}$ for 2 , chemical shifts of a keto carbonyl carbon peak at $\delta 188.33$ and three carbons, $-\mathbf{C}=\mathrm{C}(\mathrm{CN})_{2},-\mathbf{C} \equiv \mathrm{N}$, and $=\mathbf{C}(\mathrm{CN})_{2}$, in 1,1-dicyanoethylenyl (DCE) moiety of $\mathbf{2}$ at $\delta 167.64,112.99$, and 88.07, respectively, in their ${ }^{13} \mathrm{C}-\mathrm{NMR}$ spectra [Figure 2(b) and (d)], clearly consistent with both structures. Chemical shift of the former carbonyl carbon peak agrees well with that of BrDPAF-C 18 at $\delta 190.99$ [Figure 2(a)]. The $\delta$ values of the latter three DCE carbons were also found to match well with those of BrCPAF- $\mathrm{C}_{2 \mathrm{M}} 9$ [Figure 2(c)] at $\delta 170.85,112.98,(-\mathbf{C} \equiv \mathrm{N}), 112.11(-\mathrm{C} \equiv \mathrm{N})$, and 84.48, respectively. In the same spectra, the peaks at $\delta 40.14 / 41.22$ and $72.48 / 72.30$ were assigned to the cyclopropanyl or methanofullerene carbon $\mathrm{C}_{61}\left(\mathrm{C}_{60}>\right)$ and fullerenyl $\mathrm{sp}^{3}$ carbons of $\mathbf{1 / 2}$, respectively. The rest of aromatic carbon peaks were separated from each other into three different groups with 
assigned chemical shifts of (i) three aminoaryl carbons of $\mathbf{1} / \mathbf{2}$ at $\delta(153.55,151.20,148.77) /(151.83$, 150.31, 149.45) in close resemblance to those of $\mathbf{8}$ and $\mathbf{9}$, respectively, (ii) phenyl and fluorenyl carbons at $\delta 115-135$, and (iii) fullerenyl $\mathrm{sp}^{2}$ carbons located at $\delta 136-148$, as shown in Figure 2. A total of 30 fullerenyl carbon $(28 \times 2 \mathrm{C}$ and $2 \times 1 \mathrm{C})$ signals, some with similar or slightly shifted $\delta$, were accounted for $58 \mathrm{sp}^{2}$ fullerenyl carbons that fits well with a $C_{2}$ molecular symmetry of the compounds 1 and 2.

Figure 1. Infrared spectra of (a) BrCPAF-C $2 \mathrm{M}$ 9, (b) $\mathrm{C}_{60}\left(>\mathrm{DPAF}_{-\mathrm{C}_{18}}\right) \mathbf{1}$, (c) $\mathrm{C}_{60}\left(>\mathrm{DPAF}_{2} \mathrm{C}_{2 \mathrm{M}}\right)$ $\left(>\mathrm{CPAF}_{\left.-\mathrm{C}_{2 \mathrm{M}}\right)} \mathbf{3},(\mathbf{d}) \mathrm{C}_{60}\left(>\mathrm{DPAF}-\mathrm{C}_{18}\right)\left(>\mathrm{CPAF}-\mathrm{C}_{2 \mathrm{M}}\right)_{2} \mathbf{4}\right.$, and $(\mathbf{e}) \mathrm{C}_{60}\left(>\mathrm{CPAF}-\mathrm{C}_{2 \mathrm{M}}\right) 2$.

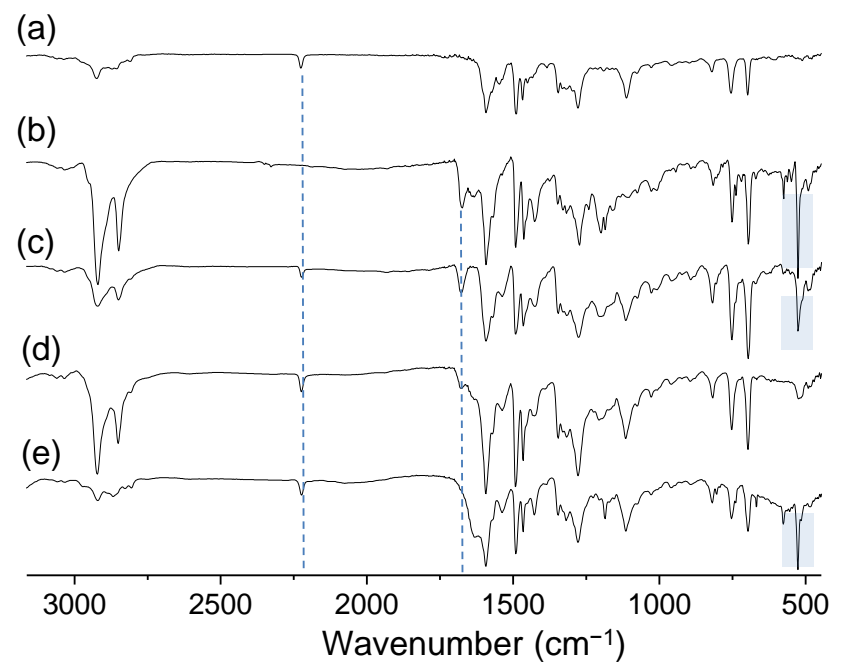

Figure 2. ${ }^{13} \mathrm{C}-\mathrm{NMR}$ spectra of (a) BrDPAF-C ${ }_{18}$ 8, (b) $\mathrm{C}_{60}\left(>\mathrm{DPAF} \mathrm{C}_{18}\right) \mathbf{1}$, (c) $\mathrm{BrCPAF}_{2 \mathrm{M}}$ 9, and (d) $\mathrm{C}_{60}\left(>\mathrm{CPAF}-\mathrm{C}_{2 \mathrm{M}}\right) 2$ with three regions of carbon peaks marked by blue, green, and brown.

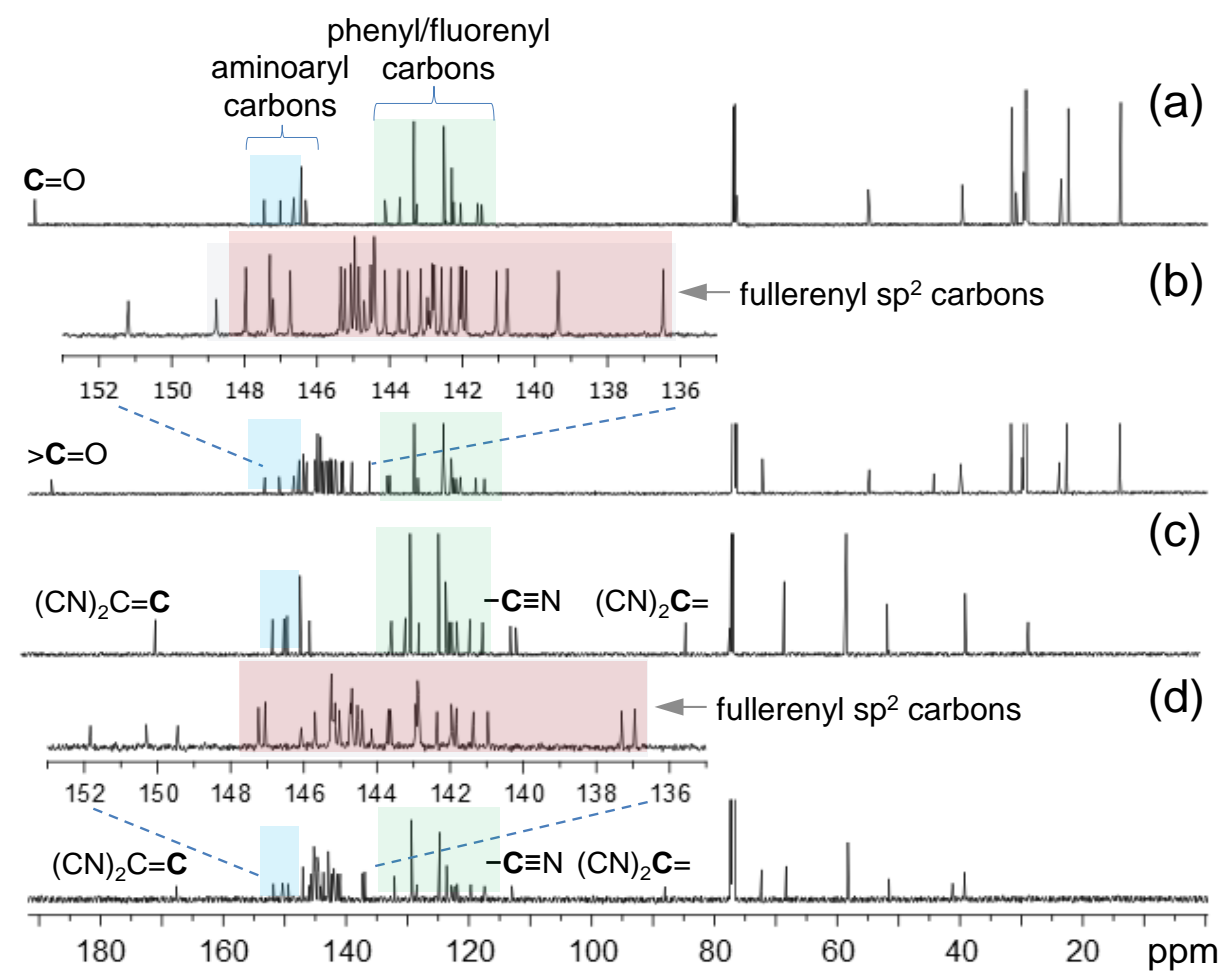


With well-characterized structures of $\mathbf{1}$ and $\mathbf{2}$, we were able to utilize their ${ }^{1} \mathrm{H}-\mathrm{NMR}$ spectra for the correlation and identification of hybrid [60]fullerene triads 3 and tetrads 4 . Upon the attachment of one CPAF- $\mathrm{C}_{2 \mathrm{M}}$ antenna arm to $\mathbf{1}$, a new cyano stretching band centered at $2,223 \mathrm{~cm}^{-1}$ in addition to the carbonyl stretching band at $1678 \mathrm{~cm}^{-1}$ were detected as expected. Intensity of characteristic half-fullerene cage absorption band at $\sim 526 \mathrm{~cm}^{-1}$ was found to decrease significantly going from that of $\mathbf{1}, \mathbf{3}$, to 4 (Figure 1) indicating the increasing percentage of regioisomers having at least one CPAF- $\mathrm{C}_{2 \mathrm{M}}$ addend located at more than $90^{\circ}$ away the DPAF- $\mathrm{C}_{18}$ arm (or the other side of the cage surface). Large difference of ${ }^{1} \mathrm{H}$ chemical shifts among alkyl groups of DPAF- $\mathrm{C}_{18}$ (methyl and the most of methylene proton peaks at $\delta$ 0.69-1.29) and $\mathrm{CPAF}_{2} \mathrm{C}_{2 \mathrm{M}}$ (singlet terminal methoxy $\mathrm{CH}_{3}-\mathrm{O}-$ proton peak at $\delta 2.95$ and triplet methylenoxy $-\mathrm{CH}_{2}-\mathrm{O}$ - proton peaks centered at $\delta 2.73$ ) allowed us to measure a clear proton integration count to verify the structure of $\mathbf{3}$ and $\mathbf{4}$ as a bisadduct and trisadduct, respectively, as shown in Figure 3. A more branched structure of $\mathbf{4}$ was also evident by the detection of a higher aromatic proton integration ratio in the region of $\delta 7.5-7.8$ and 8.10-8.15 [Figure 3(b) and (e)] of CPAF moieties. The most distinguishable proton peaks at $\delta 5.5-5.7$ in these spectra were assigned for $\alpha$-protons each bound on the cyclopropanyl carbon located between either the keto (for DPAF) or DCE (for CPAF) group and the $\mathrm{C}_{60}$ cage. Owing to the fullerenyl ring current, a large down-field shift of the $\delta$ value was observed at $\delta 5.66$ (for the keto $\alpha-\mathrm{H}$ ) and 5.51 (for the DCE $\alpha-\mathrm{H}$ ) from that of the fluorenyl $\alpha$-bromoketo $\alpha-\mathrm{H}$ at $\delta 4.61$ [Figure 3(a-c)] or $\delta 2.6$ for the fluorenyl keto $\alpha$-H (without $\alpha$-attachment of a bromine atom, a large shift of $\sim 3.0 \mathrm{ppm}$ ). It also caused a down-field $\delta$ shift of 0.44-0.48 ppm for fluorenyl protons located at the vicinity of $\mathrm{C}_{60}>$ moiety that clearly revealed strong electronic interactions between DPAF- $\mathrm{C}_{18} / \mathrm{CPAF}-\mathrm{C}_{2 \mathrm{M}}$ antenna moieties and the fullerene cage.

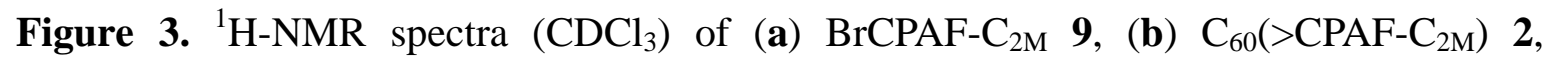

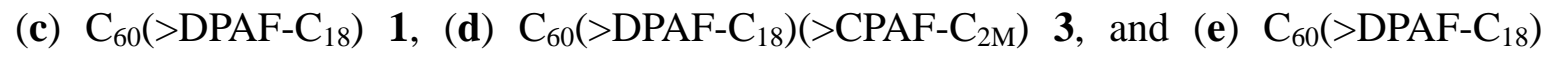
$\left(>\mathrm{CPAF}-\mathrm{C}_{2 \mathrm{M}}\right)_{2} 4$.

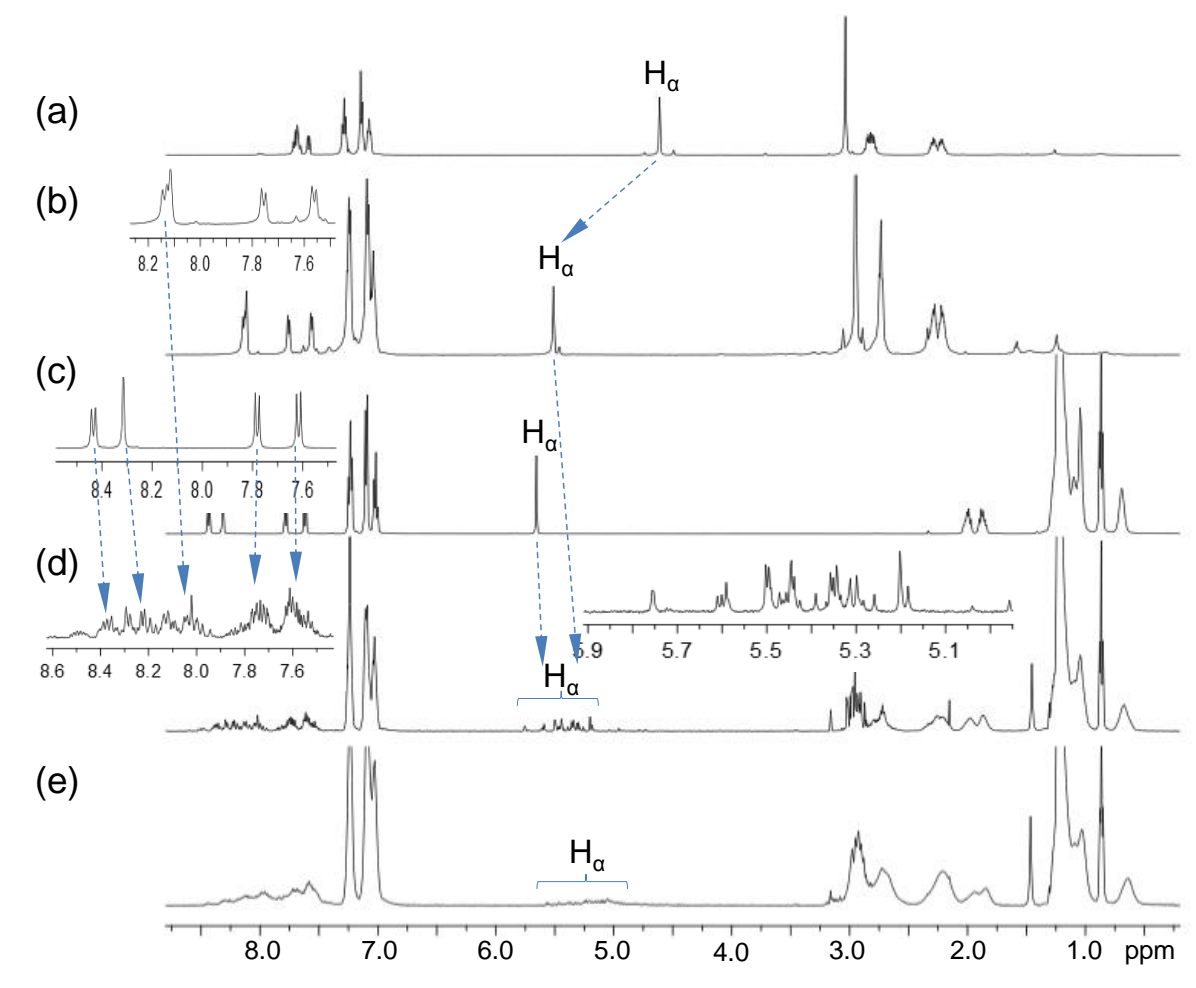


A number of $\alpha-\mathrm{H}$ peaks were observed in the ${ }^{1} \mathrm{H}-\mathrm{NMR}$ spectrum of $\mathbf{3}$ [the inset of Figure 3(d)]. By taking the consideration of four possible different orientational configurations for each regioisomer, as examples shown in Figure 4, one regioisomeric molecule may display four keto $\alpha-\mathrm{H}_{\text {a }}$ peaks (from the DPAF- $\mathrm{C}_{18}$ moiety) and four DCE $\alpha-\mathrm{H}_{\mathrm{b}}$ peaks (from the CPAF- $\mathrm{C}_{2 \mathrm{M}}$ moiety) in the region of $\delta 5.0-5.75$. Therefore, detected $\alpha-\mathrm{H}_{\mathrm{a}}$ peaks each in different intensities can be separately grouped into and accounted for two major regioisomer products and one minor regioisomer product. High similarity of molecular polarity among these regioisomers prohibited us to separate them chromatographically. However, we were able to confirm the identical composition mass of these regioisomers by detecting an group of sharp molecular mass ions with the maximum mass at $\mathrm{m} / \mathrm{z}, 2,136\left(\mathrm{MH}^{+}\right)$, as shown in Figure 5(a). It was accompanied by a relatively simple MALDI-TOF mass spectrum showing fully fragmented mass ions at $m / z, 763,735$, and 720 corresponding clearly to the mass of $\mathrm{C}_{60}[>(\mathrm{C}=\mathrm{O})-\mathrm{H}] \mathrm{H}^{+}$, $\mathrm{C}_{60}>\mathrm{H}^{+}, \mathrm{C}_{60}{ }^{+}$, respectively, that was consistent well with the molecular structure of triad $\mathrm{C}_{60}\left(>\mathrm{DPAF}_{-} \mathrm{C}_{18}\right)\left(>\mathrm{CPAF}-\mathrm{C}_{2 \mathrm{M}}\right)$ 3. In the case of tetrad $\mathrm{C}_{60}\left(>\mathrm{DPAF}_{-\mathrm{C}_{18}}\right)\left(>\mathrm{CPAF}-\mathrm{C}_{2 \mathrm{M}}\right)_{2}$ 4, a group of sharp molecular mass ions with the maximum mass at $m / z, 2,673\left(\mathrm{MH}^{+}\right)$and similar fragmented mass ions to those of $\mathbf{3}$ in the low mass region of $m / z, 720-1,000$ were detected [Figure 5(b)]. These MS data revealed high stability of aromatic diphenylaminofluorene moiety under measurement conditions. Additional high mass groups of peaks with the peak maximum at $\mathrm{m} / \mathrm{z} 2160$ of Figure $5(\mathrm{a})$ and $\mathrm{m} / \mathrm{z}$ 2,696 of Figure 5(b) are satellite peaks with an increase of $2 \mathrm{C}(\mathrm{m} / \mathrm{z} 24)$ mass from those of molecular ion mass peaks, as common phenomena for fullerenyl nanocarbon materials, especially, under the high laser power conditions used for the collection of high mass ions. The fragmentation pattern fits well with the bond cleavage occurring mostly at the cyclopropanyl carbon bonds bridging the $\mathrm{C}_{60}$ cage and DPAF- $\mathrm{C}_{18} / \mathrm{CPAF}-\mathrm{C}_{2 \mathrm{M}}$ antenna moiety. The overall spectra provided strong evidence for the mass composition of $\mathbf{3}$ and $\mathbf{4}$.

Figure 4. Four possible structural conformers for each regioisomer of $\mathrm{C}_{60}\left(>\mathrm{DPAF}_{-\mathrm{C}_{18}}\right)\left(>\mathrm{CPAF}-\mathrm{C}_{2 \mathrm{M}}\right) \mathbf{3}$.

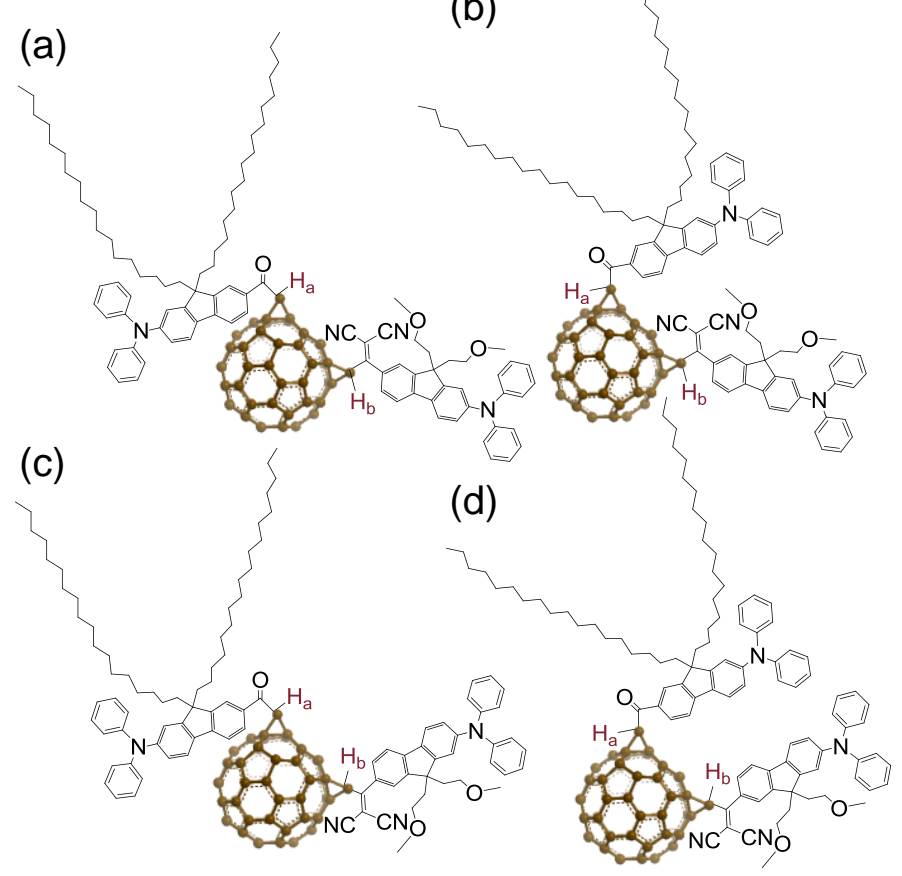


Figure 5. MALDI mass spectra of (a) $\mathrm{C}_{60}\left(>\mathrm{DPAF}_{-} \mathrm{C}_{18}\right)\left(>\mathrm{CPAF} \mathrm{C}_{2 \mathrm{M}}\right) \quad \mathbf{3}$ and (b) $\mathrm{C}_{60}\left(>\mathrm{DPAF}^{-\mathrm{C}_{18}}\right)\left(>\mathrm{CPAF}-\mathrm{C}_{2 \mathrm{M}}\right)_{2} 4$.

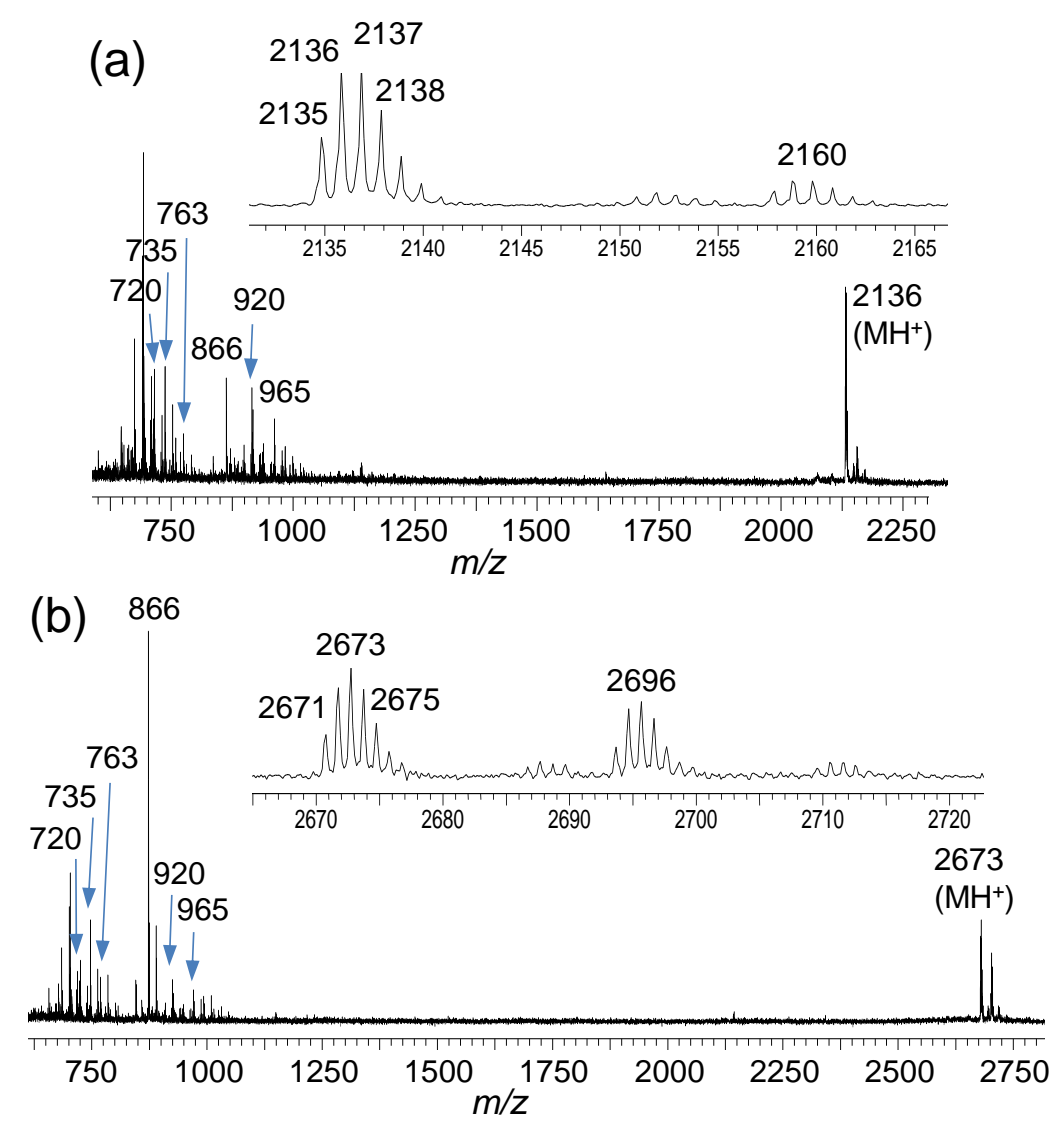

Optical absorption of $\mathbf{1}$ and 2 [Figure 6(d) and (c), respectively] was characterized by two distinguishable bands centered at 260 and $325-327 \mathrm{~nm}$ both arising from the $\mathrm{C}_{60}>$ cage moiety that agrees with allowed ${ }^{1} \mathrm{~T}_{1 \mathrm{u}} \rightarrow{ }^{1} \mathrm{~A}_{\mathrm{g}}$ transition bands of pristine $\mathrm{C}_{60}$ [29]. The third band with $\lambda_{\max }$ at either 411 or $501 \mathrm{~nm}$ for $\mathbf{1}$ or $\mathbf{2}$, respectively, matches approximately with those of the corresponding precursor compound BrDPAF-C ${ }_{18}$ [Figure 6(a)] or BrCPAF- $\mathrm{C}_{2 \mathrm{M}}$ [Figure 6(b)]. These bands are in the characteristic photoresponsive wavelength range of DPAF- $\mathrm{C}_{18}$ or $\mathrm{CPAF}_{2 \mathrm{M}} \mathrm{C}_{2 \mathrm{M}}$ antenna, respectively. When these two types of antenna were simultaneously attached to the same $\mathrm{C}_{60}$ in $\mathbf{3}$, two absorption bands with $\lambda_{\max }(\varepsilon)$ at $413\left(3.9 \times 10^{4}\right)$ and $494 \mathrm{~nm}\left(2.3 \times 10^{4} \mathrm{~L} / \mathrm{mol}-\mathrm{cm}\right)$ were observed in the spectrum showing extinction coefficient $\varepsilon$ values matching roughly with those of $\mathbf{1}$ and $\mathbf{2}$. This clearly revealed a 1:1 ratio of DPAF- $\mathrm{C}_{18} / \mathrm{CPAF}-\mathrm{C}_{2 \mathrm{M}}$ in 3 consistent with its composition. As the number of CPAF- $\mathrm{C}_{2 \mathrm{M}}$ antenna being increased to two in 4 , the corresponding two bands remained in the same range with $\lambda_{\max }$ $(\varepsilon)$ at $417\left(4.6 \times 10^{4}\right)$ and $500 \mathrm{~nm}\left(4.6 \times 10^{4} \mathrm{~L} / \mathrm{mol}-\mathrm{cm}\right)$. The extinction coefficient $\varepsilon$ value of the second band is nearly double to that of $\mathbf{3}$. The structural modification resulted in approximately equal visible absorption in intensity over the full wavelength range of 400-550 $\mathrm{nm}$. Accordingly, these bands can be utilized for the corresponding near-IR two-photon absorption excitation at $800-1,100 \mathrm{~nm}$, giving broadband characteristics of the materials while exhibiting good linear transparency beyond $800 \mathrm{~nm}$ [Figure 6(e) and (f)]. In the long-wavelength absorption region beyond $650 \mathrm{~nm}$, a very weak characteristic steady-state absorption band of methano[60]fullerene $\left(\mathrm{C}_{60}>\right)$ moiety became noticeable at $695 \mathrm{~nm}$ only at an increased concentration of $4.5 \times 10^{-4} \mathrm{M}$ in $\mathrm{CHCl}_{3}$. 
Figure 6. UV-vis spectra of (a) BrDPAF- $\mathrm{C}_{18}$ 8, (b) $\mathrm{BrCPAF}_{-\mathrm{C}_{2 \mathrm{M}}}$ 9, (c) $\mathrm{C}_{60}\left(>\mathrm{CPAF}-\mathrm{C}_{2 \mathrm{M}}\right) \mathbf{2}$,

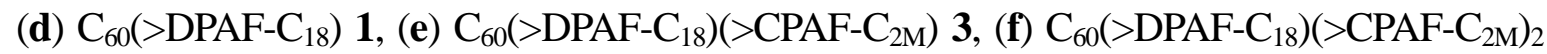
$\mathbf{4}$, in chloroform at a concentration of $1.0 \times 10^{-5} \mathrm{M}$.

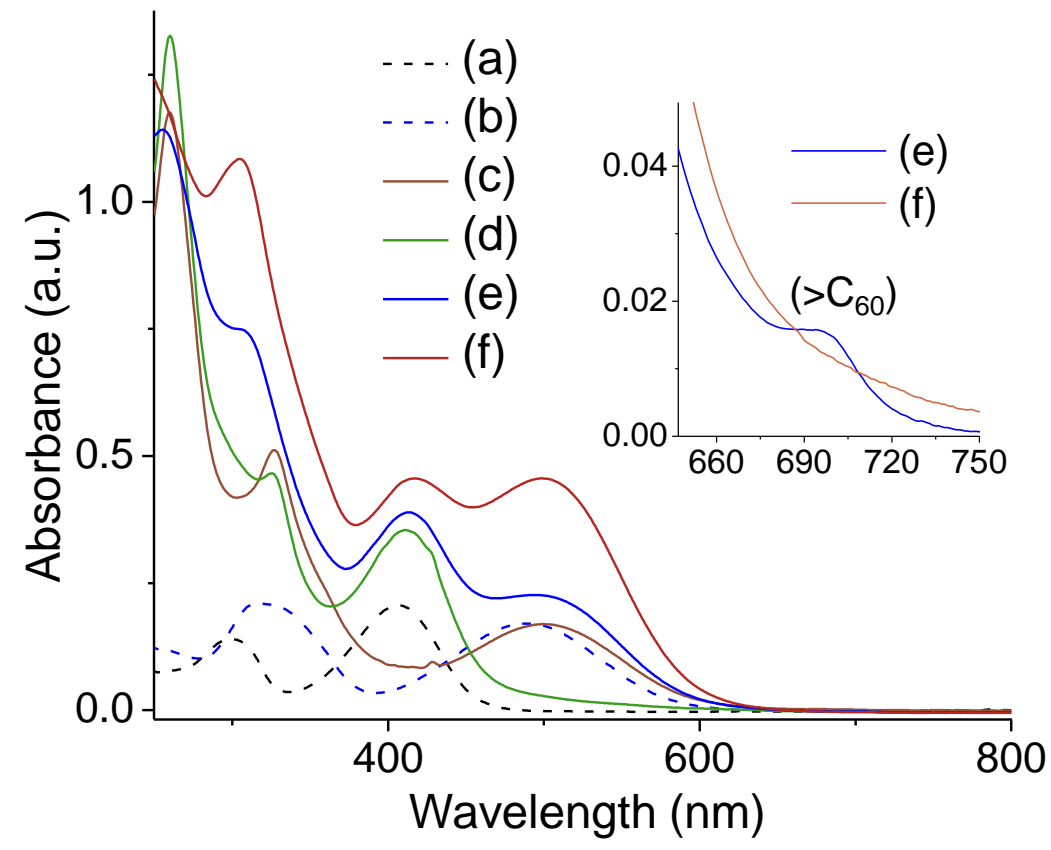

It is noteworthy that excited state intramolecular energy-transfer resonance phenomena between the DPAF- $\mathrm{C}_{18}$ and CPAF- $\mathrm{C}_{2 \mathrm{M}}$ antenna around the cage surface of $\mathbf{3}$ and $\mathbf{4}$ were observed. We first characterized the steady-state fluorescence (FL) emission of each antenna component using the model compound a-DPAF- $\mathrm{C}_{2} 10$ and a-CPAF- $\mathrm{C}_{2} 11$ (Scheme 1) in toluene as the spectroscopic reference. Upon photoexcitation of $\mathbf{1 0}$ at $410 \mathrm{~nm}$ to match with the optical absorption band of DPAF- $\mathrm{C}_{18}$, strong fluorescence emissions of ${ }^{1}\left(\mathrm{a}-\mathrm{DPAF}-\mathrm{C}_{2}\right) *$ centered at $481 \mathrm{~nm}\left(\lambda_{\max , \mathrm{em}}\right)$ [Figure 7A(a)] were detected. Likewise, strong FL emissions of ${ }^{1}\left(\mathrm{a}-\mathrm{CPAF}-\mathrm{C}_{2}\right)^{*}$ centered at $543 \mathrm{~nm}\left(\lambda_{\text {max,em }}\right)$ [Figure $7 \mathrm{~B}(\mathrm{a})$ ] were observed when 11 was irradiated at $478 \mathrm{~nm}$ which matches with the optical absorption band of CPAF- $\mathrm{C}_{2 \mathrm{M}}$. As expected, highly efficient intramolecular fluorescence quenching of these two bands by $\mathrm{C}_{60}$ occurred when $\mathbf{1}$ and $\mathbf{2}$ were photoexcited at the same corresponding light wavelength, as shown in Figure $7 \mathrm{~A}(\mathrm{~b})$ and $7 \mathrm{~B}(\mathrm{~b})$, respectively. This photophysical event led to the subsequent emission from the ${ }^{1}\left(\mathrm{C}_{60}>\right)^{*} \rightarrow{ }^{1}\left(\mathrm{C}_{60}>\right)_{0}$ transition at 704 and $708 \mathrm{~nm}$, respectively. The possible phosphorescence emission from ${ }^{3}\left(\mathrm{C}_{60}>\right)^{*} \rightarrow{ }^{1}\left(\mathrm{C}_{60}>\right)_{0}$ transition expected at $\sim 800-850 \mathrm{~nm}$ was too weak to be detected. In the case of the bisadduct $\mathrm{C}_{60}\left(>\mathrm{DPAF}-\mathrm{C}_{18}\right)_{2}$, two FL bands with $\lambda_{\max }$ at 451 and 525 (shoulder) $\mathrm{nm}$ [Figure $7 \mathrm{~A}(\mathrm{c})$ ] were shown, indicating incomplete quenching of $\mathrm{C}_{60}\left[>{ }^{1}(\mathrm{DPAF}) *-\mathrm{C}_{18}\right]_{2}$ by $\mathrm{C}_{60}>$ when the number of antenna are more than one. Similarly, three fluorescence bands with $\lambda_{\max }$ at 506, 531, and 615 (broad) $\mathrm{nm}$ [Figure $7 \mathrm{~B}(\mathrm{c})$ ] were found for the bisadduct $\mathrm{C}_{60}\left(>\mathrm{CPAF}-\mathrm{C}_{2 \mathrm{M}}\right)_{2}$. Owing to high similarity on the structural moieties, these FL bands were used as the reference for the FL spectroscopic characterization of $\mathbf{3}$ and $\mathbf{4}$. 
Figure 7. Steady-state fluorescence spectra of (A) (a) 10, (b) 1 (including a Raman peak at $470 \mathrm{~nm}),(\mathbf{c}) \mathrm{C}_{60}\left(>\mathrm{DPAF}_{-\mathrm{C}_{18}}\right)_{2}$, (d) 3, and (e) 4 at the excitation wavelength of $410 \mathrm{~nm}$ and (B) (a) 11, (b) 2 (including a Raman peak at $558 \mathrm{~nm}$ ), (c) $\mathrm{C}_{60}\left(>\mathrm{CPAF}-\mathrm{C}_{2 \mathrm{M}}\right)_{2}$, (d) 3, and (e) 4 at the excitation wavelength of $478 \mathrm{~nm}$. The concentration of all samples was $1.0 \times 10^{-5}$ $\mathrm{M}$ in toluene.
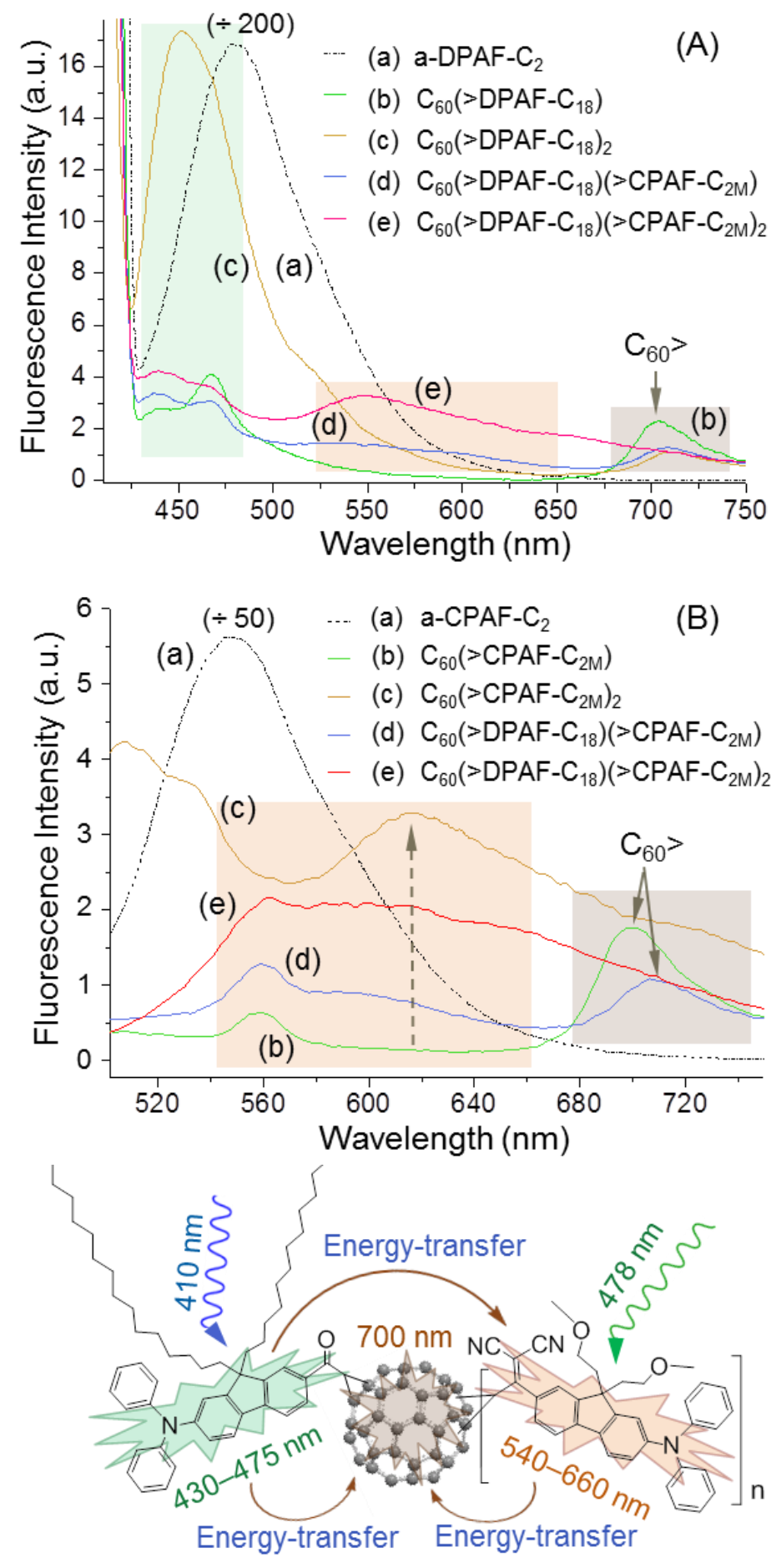

Interestingly, upon photoexcitation of the triad 3 specifically on the DPAF- $\mathrm{C}_{18}$ antenna moiety at $410 \mathrm{~nm}$, the resulting FL spectrum [Figure 7A(d)] displayed a weak broad FL band at 448 [from $\left.{ }^{1}(\mathrm{DPAF}) *-\mathrm{C}_{18}\right]$ and broad bands at $525-650 \mathrm{~nm}$ along with the ${ }^{1}\left(\mathrm{C}_{60}>\right)^{*}$ emission band centered at $708 \mathrm{~nm}$. The latter broad bands fit in the similar range as those of $\mathrm{C}_{60}\left[>{ }^{1}(\mathrm{CPAF}) *-\mathrm{C}_{2 \mathrm{M}}\right]_{2}$. As the number of 
CPAF- $\mathrm{C}_{2 \mathrm{M}}$ antenna being increased by one to the structure of tetrad $\mathrm{C}_{60}\left(>\mathrm{DPAF}-\mathrm{C}_{18}\right)\left(>\mathrm{CPAF}-\mathrm{C}_{2 \mathrm{M}}\right)_{2} 4$, the intensity of broad FL bands at 525-650 nm became more pronounced while retaining the same intensity of the ${ }^{1}\left(\mathrm{C}_{60}>\right)^{*}$ emission band at $709 \mathrm{~nm}$ [Figure $\left.7 \mathrm{~A}(\mathrm{e})\right]$. The data revealed intramolecular Förster energy-transfer resonance from the photoexcited $\mathrm{C}_{60}\left[>{ }^{1}(\mathrm{DPAF}) * \mathrm{C}_{18}\right]\left(>\mathrm{CPAF}-\mathrm{C}_{2 \mathrm{M}}\right)_{2}$ state to both ${ }^{1} \mathrm{C}_{60} *\left(>\mathrm{DPAF}-\mathrm{C}_{18}\right)\left(>\mathrm{CPAF}-\mathrm{C}_{2 \mathrm{M}}\right)_{2}$ and $\mathrm{C}_{60}\left(>\mathrm{DPAF} \mathrm{C}_{18}\right)\left[>{ }^{1}(\mathrm{CPAF}) *-\mathrm{C}_{2 \mathrm{M}}\right]_{2}$ states. The latter energy-transfer is possible since: (i) the energy level of ${ }^{1}(\mathrm{CPAF})^{*}-\mathrm{C}_{2 \mathrm{M}}$ is lower than that of ${ }^{1}(\mathrm{DPAF})^{*}$ $\mathrm{C}_{18}$, (ii) the energy of this FL band at $430-475 \mathrm{~nm}$ is slightly higher than that of the CPAF-C $\mathrm{C}_{2 \mathrm{M}}$ absorption $\lambda_{\max }$ at $500 \mathrm{~nm}$, and (iii) there is a partial overlap of emission/absorption bands to enhance the energy-transfer efficiency. Conversely, photoexcitation of $\mathbf{3}$ specifically on the CPAF- $\mathrm{C}_{2 \mathrm{M}}$ antenna moiety at $478 \mathrm{~nm}$, the resulting FL spectrum [Figure 7B(d)] showed only a weak broad FL band at 540-660 nm along with the ${ }^{1}\left(\mathrm{C}_{60}>\right)^{*}$ emission band centered at $707 \mathrm{~nm}$. Intensity of the former broad band was significantly increased using 4 [Figure $7 \mathrm{~B}(\mathrm{e})$ ] with photoexcitation on both two CPAF- $\mathrm{C}_{2 \mathrm{M}}$ antenna moieties. This confirmed the band was contributed from the $\mathrm{C}_{60}\left(>\mathrm{DPAF}-\mathrm{C}_{18}\right)\left[{ }^{1}(\mathrm{CPAF})^{*}-\mathrm{C}_{2 \mathrm{M}}\right]_{2}$ state, which was capable of inducing the ${ }^{1} \mathrm{C}_{60} *\left(>\mathrm{DPAF}-\mathrm{C}_{18}\right)\left(>\mathrm{CPAF}-\mathrm{C}_{2 \mathrm{M}}\right)_{2}$ state subsequently.

Data of femtosecond Z-scans and nonlinear light-intensity transmittance reduction measurements of $\mathrm{C}_{60}\left(>\mathrm{CPAF}-\mathrm{C}_{9}\right), \mathbf{3}$, and $\mathbf{4}$, performed as a function of irradiance intensity using 125 -fs laser pulses at either $780 \mathrm{~nm}$ (corresponding to the two-photon absorption of DPAF moieties) or $980 \mathrm{~nm}$ (corresponding to the two-photon absorption of CPAF moieties) at the concentration of $5 \times 10^{-3} \mathrm{M}$ in toluene, were provided in the supporting information. These data substantiated the nonlinear photonic characteristics of $\mathbf{3}$ and $\mathbf{4}$ showing dual NIR two-photon absorption capability that led to large nonlinear light-transmittance reduction in intensity in these two wavelength ranges up to the fs-laser fluence of $120 \mathrm{GW} / \mathrm{cm}^{2}$. Observed sufficiently large two-photon absorption cross-section values of 3 and 4 may allow their uses as the nanocarbon core of $2 \gamma$-PDT agents after the chemical modification with water-soluble side-chains and cationic targeting segments on the fluorene ring moiety.

\section{Experimental}

\subsection{Materials}

The reagents 1,8-diazabicyclo[5,4,0]-undec-7-ene (DBU), 1-bromooctadecane, 2-bromofluorene, sodium $t$-butoxide, potassium $t$-butoxide, aluminum chloride, titanium chloride, rac-BINAP, tris(dibenzylideneacetone)dipalladium(0), malononitrile, and 2-methoxy-ethanol, were purchased from Aldrich Chemicals (city, state abbrev, USA) and used without further purification. The chemical 1-bromooctadecane was purchased from Tokyo Chemical Industry Co., Ltd. (Waltham, MA, USA). A $\mathrm{C}_{60}$ sample with a purity of $99.0 \%$ was purchased from Term USA, Inc. (Fort Bragg, CA, USA). Both $\mathrm{C}_{60}\left(>\mathrm{DPAF}-\mathrm{C}_{18}\right)_{2}$ and $\mathrm{C}_{60}\left(>\mathrm{CPAF}-\mathrm{C}_{2 \mathrm{M}}\right)_{2}$ were synthesized by the similar methods described below.

\subsection{Spectroscopic Measurements}

Infrared spectra were recorded as $\mathrm{KBr}$ pellets on a Thermo Nicolet Avatar 370 FT-IR spectrometer. ${ }^{1} \mathrm{H}-\mathrm{NMR}$ and ${ }^{13} \mathrm{C}$-NMR spectra were recorded on a Bruker Avance Spectrospin-500 spectrometer. UV-vis spectra were recorded on a Perkin Elmer Lambda 750 UV-vis-NIR Spectrometer. Photoluminescence (PL) spectra were measured using PTI Fluorescence Master Systems connected 
with a photomultiplier (914 Photomultiplier Detection System) with Xenon short arc lamp as the excitation source. Mass spectroscopic measurements were performed by the use of positive ion matrixassisted laser desorption ionization (MALDI-TOF) technique on a micromass M@LDI-LR mass spectrometer. The sample blended or dissolved in the matrix material was irradiated by nitrogen UV laser at $337 \mathrm{~nm}$ with $10 \mathrm{~Hz}$ pulses under high vacuum. Mass ion peaks were identified for the spectrum using the MassLynx v4.0 software. In a typical experiment, the samples of $\mathrm{C}_{60}\left(>\mathrm{DPAF}-\mathrm{C}_{18}\right)$, $\mathrm{C}_{60}\left(>\mathrm{CPAF}-\mathrm{C}_{2 \mathrm{M}}\right), \mathrm{C}_{60}\left(>\mathrm{DPAF}-\mathrm{C}_{18}\right)\left(>\mathrm{CPAF}-\mathrm{C}_{2 \mathrm{M}}\right)$, or $\mathrm{C}_{60}\left(>\mathrm{DPAF} \mathrm{C}_{18}\right)\left(>\mathrm{CPAF}-\mathrm{C}_{2 \mathrm{M}}\right)_{2}$ were dissolved in $\mathrm{CHCl}_{3}$ in a concentration of $1.0 \mathrm{mg} / \mathrm{mL}$. The matrix of 3,5-dimethoxy-4-hydroxycinnamic acid (sinapic acid) was dissolved in THF in a concentration of $10 \mathrm{mg} / \mathrm{mL}$. The solution of matrix $(1.0 \mathrm{~mL})$ was taken and mixed with the sample solution $(0.1 \mathrm{~mL})$ prior to the deposition on a stainless-steel MALDI target probe. It was subsequently dried at ambient temperature.

\subsection{Synthetic Procedures}

\subsubsection{Synthesis of 9,9-Di(2-methoxyethyl)-2-diphenylaminofluorene, DPAF- $\mathrm{C}_{2 \mathrm{M}}(\mathbf{6})$}

Part A: In a round-bottom flask containing a mixture of triethylamine $(19.9 \mathrm{~mL}, 0.14 \mathrm{~mol})$, 2-methoxyethanol $(10.3 \mathrm{~mL}, 0.13 \mathrm{~mol})$, and anhydrous dichloroethane $(150 \mathrm{~mL})$ at $0{ }^{\circ} \mathrm{C}$ was added methanesulfonyl chloride $(11.1 \mathrm{~mL}, 0.14 \mathrm{~mol})$ over a period of $20 \mathrm{~min}$. The mixture was warmed to ambient temperature under a nitrogen atmospheric pressure and stirred for $12 \mathrm{~h}$. It was quenched by the addition of water and washed with water $(2 \times 150 \mathrm{~mL})$, dilute hydrochloric acid $(1 \times 100 \mathrm{~mL})$, and saturated sodium bicarbonate $(1 \times 100 \mathrm{~mL})$ in sequence. The organic layer was dried over sodium sulfate and concentrated in vacuo. The crude brownish liquid was vacuum distilled at $120-130{ }^{\circ} \mathrm{C}$ to afford 2-methoxyethylmethanesulfonate $(17.9 \mathrm{~g})$ in a nearly quantitative yield; ${ }^{1} \mathrm{H}-\mathrm{NMR}\left(\mathrm{CDCl}_{3}, \mathrm{ppm}\right)$ $\delta 4.36(\mathrm{t}, J=4.41 \mathrm{~Hz}, 2 \mathrm{H}), 3.66(\mathrm{t}, J=4.41 \mathrm{~Hz}, 2 \mathrm{H}), 3.40(\mathrm{~s}, 3 \mathrm{H})$, and $3.05(\mathrm{~s}, 3 \mathrm{H})$.

Part B: In a round-bottom flask containing a mixture of 2-diphenylaminofluorene 5 (DPAF) $(0.52 \mathrm{~g}, 1.56 \mathrm{mmol})$ and potassium $t$-butoxide $(0.38 \mathrm{~g}, 3.39 \mathrm{mmol})$ in dry THF $(30 \mathrm{~mL})$ at $0{ }^{\circ} \mathrm{C}$ was added 2-methoxyethylmethanesulfonate $(10.53 \mathrm{~g}, 3.4 \mathrm{mmol})$ over $10 \mathrm{~min}$. The mixture was warmed to ambient temperature under a nitrogen atmosphere and stirred for $4.0 \mathrm{~h}$. The reaction mixture was washed with brine $(20 \mathrm{~mL})$ and water $(20 \mathrm{~mL})$. Organic layer was dried over sodium sulfate and concentrated in vacuo. The crude product was then purified by column chromatography [silica gel, toluene-ethyl acetate (3:1) as the eluent] via a chromatographic fraction corresponding to $R_{\mathrm{f}}=0.7$ on TLC $\left(\mathrm{SiO}_{2}\right)$ with the same eluent to afford DPAF-C $\mathrm{C}_{2 \mathrm{M}} 6$ as white solids in a yield of $94 \%(0.66 \mathrm{~g})$. Spectroscopic data: MALDI-MS (TOF) $\mathrm{m} / \mathrm{z}, 449$ calculated for ${ }^{12} \mathrm{C}_{31}{ }^{1} \mathrm{H}_{31}{ }^{14} \mathrm{~N}_{1}{ }^{16} \mathrm{O}_{2}$; found, $\mathrm{m} / \mathrm{z}$ $450\left(\mathrm{MH}^{+}\right) ;{ }^{1} \mathrm{H}-\mathrm{NMR}\left(\mathrm{CDCl}_{3}, \mathrm{ppm}\right) \delta 7.61(\mathrm{~d}, J=7.60 \mathrm{~Hz}, 1 \mathrm{H}), 7.55(\mathrm{~d}, J=7.55 \mathrm{~Hz}, 1 \mathrm{H}), 7.38(\mathrm{~d}$, $J=7.37 \mathrm{~Hz}, 1 \mathrm{H}), 7.31(\mathrm{t}, J=7.32 \mathrm{~Hz}, 1 \mathrm{H}), 7.28-7.24(\mathrm{~m}, 5 \mathrm{H}), 7.18-7.10(\mathrm{~m}, 6 \mathrm{H}), 7.13-7.00(\mathrm{~m}, 2 \mathrm{H})$, $3.04(\mathrm{~s}, 6 \mathrm{H}), 2.79-2.71(\mathrm{~m}, 4 \mathrm{H})$, and $2.26-2.20(\mathrm{~m}, 4 \mathrm{H}) ;{ }^{13} \mathrm{C}-\mathrm{NMR}\left(\mathrm{CDCl}_{3}, \mathrm{ppm}\right) \delta 150.66,149.32$, $148.32,147.95,140.67,135.72,129.67,127.79,127.08,124.43,124.12,123.18,120.98,119.69$, $69.08,58.77,51.45$, and 39.76 . 
3.3.2. Synthesis of 7- $\alpha$-Bromoacetyl-9,9-di(2-methoxyethyl)-2-diphenylaminofluorene, $\mathrm{BrDPAF}_{2 \mathrm{M}}(\mathbf{7})$

To a suspension of aluminum chloride $(4.8 \mathrm{~g}, 36 \mathrm{mmol})$ in 1,2-dichloroethane $(200 \mathrm{~mL})$ at $0{ }^{\circ} \mathrm{C}$ was added a solution of DPAF-C ${ }_{2 M} 6(5.44 \mathrm{~g}, 12.1 \mathrm{mmol})$ in 1,2-dichloroethane $(50 \mathrm{~mL})$. It was added $\alpha$-bromoacetyl bromide $(2.44 \mathrm{~g}, 12.1 \mathrm{mmol}$ ) over a period of $10 \mathrm{~min}$. The mixture was stirred for $4.0 \mathrm{~h}$ at $0{ }^{\circ} \mathrm{C}$. The solution was worked up by slow addition of dilute $\mathrm{HCl}(1.0 \mathrm{~N})$ solution $(50 \mathrm{~mL})$ while maintaining the temperature at $0{ }^{\circ} \mathrm{C}$. The resulting organic layer was washed subsequently with dilute brine $(2 \times 50 \mathrm{~mL})$ and water $(2 \times 50 \mathrm{~mL})$ at room temperature and dried over magnesium sulfate. It was followed by the solvent removal in vacuo. The crude products were purified by column chromatography [silica gel, hexane-ethyl acetate (4:1) as the eluent] at its chromatographic band corresponding to $R_{\mathrm{f}}=0.2$ on TLC $\left(\mathrm{SiO}_{2}\right)$ with the same eluent to afford BrDPAF-C $2 \mathrm{M}$ in $91 \%$ yield (6.3 g). Spectroscopic data: FT-IR (KBr) $v_{\max }$ 3,054 (w), 3037 (w), 2,925 (m), 2,871 (m), 2,804 (w), 1,693(w), 1,673 (m), 1,593 (s), 1,490 (s), 1,467 (m), 1,430 (w), 1,388 (w), 1,320 (w), 1,279 (s), 1,194 (w), 1,113 (m), 1,026 (w), $820(\mathrm{w}), 754(\mathrm{~m}), 697(\mathrm{~m}), 669(\mathrm{w})$, and $627(\mathrm{w}) \mathrm{cm}^{-1}$; UV-vis $\left(\mathrm{CHCl}_{3}\right) \lambda_{\max }$ (e) $299\left(1.4 \times 10^{4}\right)$ and $407\left(2.1 \times 10^{4} \mathrm{~L} / \mathrm{mol}-\mathrm{cm}\right) ;{ }^{1} \mathrm{H}-\mathrm{NMR}\left(\mathrm{CDCl}_{3}, \mathrm{ppm}\right) \delta 8.03-7.99(\mathrm{~m}, 2 \mathrm{H}), 7.69$ $(\mathrm{d}, J=7.6 \mathrm{~Hz}, 1 \mathrm{H}), 7.63(\mathrm{~d}, J=7.5 \mathrm{~Hz}, 1 \mathrm{H}), 7.34-7.09(\mathrm{~m}, 10 \mathrm{H}), 7.08-7.06(\mathrm{~m}, 2 \mathrm{H}), 4.53(\mathrm{~s}, 2 \mathrm{H})$, $3.06(\mathrm{~s}, 6 \mathrm{H}), 2.84-2.75(\mathrm{~m}, 4 \mathrm{H})$, and $2.33-2.21(\mathrm{~m}, 4 \mathrm{H}) ;{ }^{13} \mathrm{C}-\mathrm{NMR}\left(\mathrm{CDCl}_{3}\right) \delta 190.99,151.81,149.32$, $149.20,147.42,146.14,132.83,131.74,129.38,129.29,124.66,123.46,122.80,121.81,119.06$, $117.86,68.52,58.29,51.30,38.89$, and 31.05.

\subsubsection{Synthesis of 7- $\alpha$-Bromoacetyl-9,9-dioctadecyl-2-diphenylaminofluorene, BrDPAF- $\mathrm{C}_{18}(\mathbf{8})$}

Part A: In a round-bottom flask containing a mixture of 2-diphenylaminofluorene 5 (DPAF, $1.0 \mathrm{~g}$, $3.0 \mathrm{mmol})$, potassium $t$-butoxide $(1.0 \mathrm{~g}, 8.9 \mathrm{mmol})$ in dry $\mathrm{THF}(30 \mathrm{~mL})$ at $0{ }^{\circ} \mathrm{C}$ was added 1-bromooctadecane $(2.0 \mathrm{~g}, 6.0 \mathrm{mmol})$ over $10 \mathrm{~min}$. The mixture was warmed to ambient temperature under a nitrogen atmosphere and stirred overnight. The reaction mixture was washed with brine $(40 \mathrm{~mL})$ and water $(40 \mathrm{~mL})$ in sequence. The organic layer was dried over sodium sulfate and concentrated in vасио. The crude product was purified by column chromatography [silica gel, hexane-toluene (4:1) as the eluent] as a chromatographic fraction corresponding to $R_{\mathrm{f}}=0.8$ on TLC $\left(\mathrm{SiO}_{2}\right)$ with the same eluent to give 9,9-dioctadecanyl-2-diphenylaminofluorene DPAF-C 18 in $97 \%$ yield (2.44 g). Spectroscopic data: FT-IR (KBr) $v_{\max }$ 3,067 (w), 3,036 (w), 2,924 (s), 2,853 (s), 1,599 (m), 1,494 (m), 1,451 (w), 1,331 (w), 1,277 (m), 1,154 (w), 1,075 (w), 1,029 (w), 824 (w), 751 (m), $737(\mathrm{~m}), 696(\mathrm{~m}), 623(\mathrm{w})$, and $513(\mathrm{w}) \mathrm{cm}^{-1}$; MALDI-MS (TOF) $\mathrm{m} / \mathrm{z} 838$ calculated for ${ }^{12} \mathrm{C}_{61}{ }^{1} \mathrm{H}_{91}{ }^{14} \mathrm{~N}_{1}$; found, $m / z 839\left(\mathrm{MH}^{+}\right) ;{ }^{1} \mathrm{H}-\mathrm{NMR}\left(\mathrm{CDCl}_{3}, \mathrm{ppm}\right) \delta 7.63(\mathrm{~d}, J=6.9,1 \mathrm{H}), 7.58(\mathrm{~d}, J=68.2$, 1H), 7.33-7.25 (m, 7H), 7.15-7.13 (m, 5H), 7.05-7.01 (m, 3H), 1.93-1.81 (m, 4H), 1.33-1.07 (m, $60 \mathrm{H}), 0.91(\mathrm{t}, J=6.94 \mathrm{~Hz}, 6 \mathrm{H})$, and $0.73-0.62(\mathrm{~m}, 4 \mathrm{H}) ;{ }^{13} \mathrm{C}-\mathrm{NMR}\left(\mathrm{CDCl}_{3}, \mathrm{ppm}\right) \delta 152.50,148.45$, 147.44, 141.29, 136.81, 129.52, 124.12, 123.98, 123.09, 122.78, 120.70, 119.93, and 119.49.

Part B: To a suspension of aluminum chloride $(0.32 \mathrm{~g}, 2.4 \mathrm{mmol})$ in 1,2-dichloroethane $(50 \mathrm{~mL})$ at $0{ }^{\circ} \mathrm{C}$ was added a solution of DPAF-C ${ }_{18}(1.0 \mathrm{~g}, 1.2 \mathrm{mmol})$ in 1,2-dichloroethane $(30 \mathrm{~mL})$. It was then added by $\alpha$-bromoacetyl bromide $(0.30 \mathrm{~g}, 1.5 \mathrm{mmol})$ over $10 \mathrm{~min}$. The mixture was stirred for $4.0 \mathrm{~h}$ at $0{ }^{\circ} \mathrm{C}$. The solution was diluted by a slow addition of water $(100 \mathrm{~mL})$ while maintaining the reaction mixture temperature below $0{ }^{\circ} \mathrm{C}$. The resulting organic layer was washed subsequently with dilute 
hydrochloric acid $(1.0 \mathrm{~N}, 30 \mathrm{~mL})$ and water $(2 \times 30 \mathrm{~mL})$, and dried over magnesium sulfate followed by the solvent removal in vacuo. The crude yellow oil was purified by column chromatography $\left[\mathrm{SiO}_{2}\right.$, hexane-EtOAc (19:1) as the eluent] to afford BrDPAF-C ${ }_{18} 8$ in $96 \%$ yield $(1.3 \mathrm{~g})$. The product gave a chromatographic $R_{\mathrm{f}}$ at 0.5 on TLC $\left(\mathrm{SiO}_{2}\right)$ with the same eluent. Spectroscopic data: FT-IR (KBr) $v_{\max }$ 3,063 (w), 3,034 (w), 2,923 (s), 2,852 (s), 1,677 (m), 1,595 (m), 1,493 (m), 1,466 (w), 1,346 (w), 1,279 (m), 1,182 (w), 1,027 (w), $819(\mathrm{w}), 753(\mathrm{w}), 697(\mathrm{~m}), 620(\mathrm{w})$, and $508(\mathrm{w}) \mathrm{cm}^{-1}$; UV-vis $\left(\mathrm{CHCl}_{3}\right) \lambda_{\max }$ (e) $292\left(1.9 \times 10^{4}\right)$ and $407\left(2.5 \times 10^{4} \mathrm{~L} / \mathrm{mol}-\mathrm{cm}\right) ;{ }^{1} \mathrm{H}-\mathrm{NMR}\left(\mathrm{CDCl}_{3}, \mathrm{ppm}\right) \delta 7.95(\mathrm{~d}, J=8.18 \mathrm{~Hz}, 1 \mathrm{H})$, $7.93(\mathrm{~s}, 1 \mathrm{H}), 7.64(\mathrm{~d}, J=7.91 \mathrm{~Hz}, 1 \mathrm{H}), 7.59(\mathrm{~d}, J=8.23 \mathrm{~Hz}, 1 \mathrm{H}), 7.27-7.23(\mathrm{~m}, 4 \mathrm{H}), 7.14-7.12(\mathrm{~m}$, 5H), 7.05-7.02 (m, 3H), $4.49(\mathrm{~s}, 2 \mathrm{H}), 1.97-1.81(\mathrm{~m}, 4 \mathrm{H}), 1.25-1.04(\mathrm{~m}, 66 \mathrm{H}), 0.87(\mathrm{t}, J=6.78 \mathrm{~Hz}$, $6 \mathrm{H})$, and $0.72-0.55(\mathrm{br}, 4 \mathrm{H}) ;{ }^{13} \mathrm{C}-\mathrm{NMR}\left(\mathrm{CDCl}_{3}\right) \delta 190.99$ (-C=O), 153.63 (aminoaryl carbon), 151.06 (aminoaryl carbon), 148.81 (aminoaryl carbon), 147.61, 146.89, 133.96, 131.55, 129.25, 128.80, 124.36, 123.09, 122.78, 121.61, 118.82, 118.20, 55.23, 39.96, 31.90, 31.15, 29.90, 29.67, 29.64, 29.62, $29.57,29.55,29.34,29.29,23.83,22.67$, and 14.10 .

3.3.4. Synthesis of 7-(1,2-Dihydro-1,2-methano[60]fullerene-61-carbonyl)-9,9-dioctadecyl-2diphenylaminofluorene, $\mathrm{C}_{60}\left(>\mathrm{DPAF}_{-} \mathrm{C}_{18}\right)(\mathbf{1})$

To a mixture of $\mathrm{C}_{60} \quad(0.75 \mathrm{~g}, 1.1 \mathrm{mmol})$ and 7- $\alpha$-bromoacetyl-9,9-dioctadecanyl-2diphenylaminofluorene $\left(\right.$ BrDPAF- $\left._{18}, \mathbf{8}, 0.85 \mathrm{~g}, 1.1 \mathrm{mmol}\right)$ in dry toluene $(500 \mathrm{~mL})$ was added DBU $(0.18 \mathrm{ml}, 1.2 \mathrm{mmol})$ under a nitrogen atmosphere. After stirring at room temperature for $5.0 \mathrm{~h}$, suspended solids of the reaction mixture were filtered off and the filtrate was concentrated to a $10 \%$ volume. Crude product was precipitated by the addition of methanol and isolated by centrifugation (8000 rpm, $20 \mathrm{~min}$ ). The isolated solid was found to be a mixture of the monoadduct and its bisadducts. Separation of these two product fractions were made by column chromatography (silica gel) using a solvent mixture of hexane-toluene (3:2) as the eluent. The first chromatographic band corresponding to $R_{\mathrm{f}}=0.7$ on TLC $\left(\mathrm{SiO}_{2}\right.$, hexane-toluene, 3:1) afforded $\mathrm{C}_{60}\left(>\mathrm{DPAF}-\mathrm{C}_{18}\right) \mathbf{1}$ as brown solids $\left(1.12 \mathrm{~g}, 65 \%\right.$ yield based on recovered $\left.\mathrm{C}_{60}\right)$. Spectroscopic data: FT-IR (KBr) $v_{\max } 3,440(\mathrm{~m})$, 2,920 (s), 2,849 (s), 1,674 (-C=O, m), 1,632 (m), 1,593 (s), 1,491 (m), 1,463 (m), 1,427 (m), 1,346 (w), $1,331(\mathrm{w}), 1,316(\mathrm{w}), 1,273(\mathrm{~m}), 1,239(\mathrm{w}), 1,200(\mathrm{~m}), 1,186(\mathrm{w}), 1157(\mathrm{w}), 1028(\mathrm{w}), 817(\mathrm{w}), 752$ (m), $738(\mathrm{w}), 696(\mathrm{~m}), 575(\mathrm{w}), 547(\mathrm{w}), 526(\mathrm{~m})$, and $490(\mathrm{~m}) \mathrm{cm}^{-1}$; MALDI-MS (TOF) $\mathrm{m} / \mathrm{z} 1598$ calculated for ${ }^{12} \mathrm{C}_{123}{ }^{1} \mathrm{H}_{91}{ }^{14} \mathrm{~N}_{1}{ }^{16} \mathrm{O}_{1}$; found, $\mathrm{m} / \mathrm{z}$ 1,601, 1,600 $\left(\mathrm{MH}^{+}\right), 1,599,866,839,762,734$, and 720; UV-vis $\left(\mathrm{CHCl}_{3}\right) \lambda_{\max }(\varepsilon) 260\left(1.3 \times 10^{5}\right), 325\left(4.7 \times 10^{4}\right)$, and $411\left(3.6 \times 10^{4} \mathrm{~L} / \mathrm{mol}-\mathrm{cm}\right){ }^{1} \mathrm{H}-\mathrm{NMR}$ $\left(\mathrm{CDCl}_{3}, \mathrm{ppm}\right) \delta 8.43(\mathrm{~d}, J=6.9 \mathrm{~Hz}, 1 \mathrm{H}), 8.32(\mathrm{~s}, 1 \mathrm{H}), 7.78(\mathrm{~d}, J=8.0 \mathrm{~Hz}, 1 \mathrm{H}), 7.61(\mathrm{~d}, J=8.0 \mathrm{~Hz}$, 1H), 7.25-7.22 (m, 4H), 7.11-7.09 (m, 5H), 7.03-7.00 (m, 3H), $5.66(\mathrm{~s}, 1 \mathrm{H}), 2.03-1.84(\mathrm{~m}, 4 \mathrm{H})$, $1.29-1.04(\mathrm{~m}, 58 \mathrm{H}), 0.87(\mathrm{t}, J=6.88 \mathrm{~Hz}, 6 \mathrm{H})$, and $0.69(\mathrm{br}, 4 \mathrm{H}) .{ }^{13} \mathrm{C}-\mathrm{NMR}\left(\mathrm{CDCl}_{3}\right) \delta 188.33(-\mathrm{C}=\mathrm{O})$, 153.55 (aminoaryl carbon), 151.20 (aminoaryl carbon), 148.77 (aminoaryl carbon), 147.96 (2C), 147.30 (2C), 147.20 (C), 146.73 (2C), 145.35 (2C), 145.24 (2C), 145.06 (2C), 144.96 (4C), 144.85 (2C), 144.70 (C), 144.52 (2C), 144.43 (4C), 144.13 (2C), 143.74 (2C), 143.49 (2C), 143.14 (2C), 142.96 (C), 142.91 (C), 142.83 (2C), 142.76 (2C), 142.57 (2C), 142.32 (2C), 142.07 (2C), 142.00 (2C), 141.90 (2C), 141.06 (2C), 140.76 (2C), 139.36 (2C), 136.46 (2C), 133.57, 133.22, 129.22, 128.62, 124.40, 123.15, 122.83, 122.42, 121.71, 119.14, 117.78, 72.48 (fullerenyl sp ${ }^{3}$ carbons), 55.09, 44.58, 40.14 (cyclopropanyl $\mathrm{C}_{60}>$ carbon), 32.00, 30.16, 29.81, 29.56, 29.47, 24.11, 22.87, and 14.22. 
A total of 30 carbon peaks were accounted for 58 fullerenyl $\mathrm{sp}^{2}$ carbons at $\delta 136-148$ indicated a $C_{2}$-symmetry of the fullerene cage.

3.3.5. Synthesis of 7-[2-Bromo-1-(1,1-dicyanoethylenyl)-1-methyl]-9,9-di(2-dimethoxyethyl)-2diphenylaminofluorene, BrCPAF- $\mathrm{C}_{2 \mathrm{M}}(\mathbf{9})$

To a mixture of 7- $\alpha$-bromoacetyl-9,9-di(2-methoxyethyl)-2-diphenylaminofluorene (BrDPAF- $\mathrm{C}_{2 \mathrm{M}}$, 7, $2.17 \mathrm{~g}, 3.8 \mathrm{mmol})$ and malononitrile $(0.29 \mathrm{~g}, 4.4 \mathrm{mmol})$ in dry chloroform $(100 \mathrm{~mL})$ was added pyridine $(3.0 \mathrm{~mL})$ while stirring under a nitrogen atmosphere. To this solution, titanium tetrachloride $(1.0 \mathrm{~mL}$, excess) was added in. After stirring at room temperature for $5.0 \mathrm{~min}$, the reaction mixture was quenched with water $(90 \mathrm{~mL})$. The resulting organic layer was washed several times with water (100 $\mathrm{mL}$ each), dried over magnesium sulfate, and concentrated in vacuo to afford the crude orangered oil. It was purified on a preparative chromatographic plate (PTLC, $\mathrm{SiO}_{2}, \mathrm{CHCl}_{3}$ as the eluent). A product fraction collected at $R_{\mathrm{f}}=0.6$ [toluene-ethyl acetate (4:1) as the eluent] gave BrCPAF-C $2 \mathrm{M} 9$ in $89 \%$ yield $(2.1 \mathrm{~g})$. Spectroscopic data: FT-IR (KBr) $v_{\max }$ 3,058 (w), 3,035 (w), 2,924 (m), 2,870 (m), 2,855 (m), 2,809 (w), 2,226 (m), 1,593 (s), 1,547 (m), 1,490 (s), 1,468 (m), 1,451 (w), 1,384 (w), 1,346 (m), 1,318 (m), 1,279 (s), 1,191 (w), 1,113 (m), 1,028 (w), $957(\mathrm{w}), 821(\mathrm{w}), 755(\mathrm{~m}), 698(\mathrm{~m})$, and $511(\mathrm{w}) \mathrm{cm}^{-1}$; UV-vis $\left(\mathrm{CHCl}_{3}\right) \lambda_{\max }(\varepsilon) 316\left(2.1 \times 10^{4}\right)$ and $489\left(1.7 \times 10^{4} \mathrm{~L} / \mathrm{mol}-\mathrm{cm}\right) ;{ }^{1} \mathrm{H}-\mathrm{NMR}$ $\left(\mathrm{CDCl}_{3}, \mathrm{ppm}\right) \delta 7.70-7.66(\mathrm{~m}, 3 \mathrm{H}), 7.59(\mathrm{~d}, J=8.3 \mathrm{~Hz}, 1 \mathrm{H}), 7.30-7.27(\mathrm{~m}, 4 \mathrm{H}), 7.15-7.13(\mathrm{~m}, 5 \mathrm{H})$, 7.09-7.06 (m, 3H), $4.61(\mathrm{~s}, 2 \mathrm{H}), 3.03(\mathrm{~s}, 6 \mathrm{H}), 2.87-2.77(\mathrm{~m}, 4 \mathrm{H})$, and $2.32-2.18(\mathrm{~m}, 4 \mathrm{H})$; ${ }^{13} \mathrm{C}-\mathrm{NMR}$ $\left(\mathrm{CDCl}_{3}\right) \delta 170.85$ [-C=C(CN) ], 151.77 (aminoaryl carbon), 149.91 (aminoaryl carbon), 149.38 (aminoaryl carbon), 147.28, 145.72, 132.39, 130.13, 129.36, 127.92, 124.74, 123.54, 122.91, 122.55, 121.72, 119.60, $117.55,112.98(-\mathbf{C} \equiv \mathrm{N}), 112.11(-\mathrm{C} \equiv \mathrm{N}), 84.48\left[=\mathbf{C}(\mathrm{CN})_{2}\right], 68.42,58.31,51.64,38.93$, and 28.68.

3.3.6. Synthesis of 7-(1,2-Dihydro-1,2-methano[60]fullerene-61-\{1,1-dicyanoethylenyl $\})-9,9-\operatorname{di}(2-$ methoxyethyl)-2-diphenylaminofluorene, $\mathrm{C}_{60}\left(>\mathrm{CPAF}-\mathrm{C}_{2 \mathrm{M}}\right)(\mathbf{2})$

To a mixture of $\mathrm{C}_{60}(0.18 \mathrm{~g}, 0.25 \mathrm{mmol})$ and 7-[2-bromo-1-(1,1-dicyanoethylenyl)-1-methyl]-9,9di(2-methoxyethyl)-2-diphenylaminofluorene $\left(\right.$ BrCPAF-C $_{2 \mathrm{M}}, \mathbf{9}, 0.15 \mathrm{~g}, 0.24 \mathrm{mmol}$ ) in dry toluene $(150 \mathrm{~mL})$ was added 1,8-diazabicyclo[5,4,0]-undec-7-ene (DBU, 0.1 M, $2.6 \mathrm{~mL})$ under a nitrogen atmosphere. After stirring at room temperature for a period of $5.0 \mathrm{~h}$, the reaction mixture was concentrated to a volume of approximately $10 \mathrm{~mL}$. Crude product was precipitated by the addition of methanol and isolated by centrifugation $(8,000 \mathrm{rpm}, 20 \mathrm{~min})$. The precipitate was further purified by column chromatography [silica gel, toluene-ethyl acetate (4:1) as the eluent] at the corresponding chromatographic $R_{\mathrm{f}}=0.8$ on TLC $\left(\mathrm{SiO}_{2}\right)$ with the same eluent to afford $\mathrm{C}_{60}\left(>\mathrm{CPAF}-\mathrm{C}_{2 \mathrm{M}}\right) \mathbf{2}$ in $53 \%$ yield $(0.16 \mathrm{~g})$. Spectroscopic data: FT-IR (KBr) $v_{\max } 3,439(\mathrm{~s}), 2,980(\mathrm{w}), 2,920(\mathrm{~m}), 2,868(\mathrm{~m}), 2,824$ (w), $2798(\mathrm{w}), 2,224(-\mathrm{C} \equiv \mathrm{N}, \mathrm{m}), 1,629(\mathrm{~m}), 1,594(\mathrm{vs}), 1,538(\mathrm{~m}), 1,491(\mathrm{~m}), 1,466(\mathrm{~m}), 1,428(\mathrm{~m})$, 1,347 (m), 1,319 (m), 1,279 (s), 1,186 (m), 1,115 (m), 1,028 (w), $958(\mathrm{w}), 888(\mathrm{w}), 820(\mathrm{~m}), 805(\mathrm{w})$, $754(\mathrm{~m}), 697(\mathrm{~m}), 668(\mathrm{w}), 577(\mathrm{w})$, and $527(\mathrm{~m}) \mathrm{cm}^{-1}$; MALDI-MS (TOF) $\mathrm{m} / z, 257$ calculated for ${ }^{12} \mathrm{C}_{96}{ }^{1} \mathrm{H}_{31}{ }^{14} \mathrm{~N}_{3}{ }^{16} \mathrm{O}_{2}$; found, $m / z$ 1,260, 1,259, 1,258 $\left(\mathrm{MH}^{+}\right), 1,155,987,965,919,735$, and 720; UV-vis $\left(\mathrm{CHCl}_{3}\right) \lambda_{\max }(\varepsilon) 260\left(1.2 \times 10^{5}\right), 327\left(5.1 \times 10^{4}\right)$, and $501 \mathrm{~nm}\left(1.7 \times 10^{4} \mathrm{~L} / \mathrm{mol}-\mathrm{cm}\right) ;{ }^{1} \mathrm{H}-\mathrm{NMR}\left(\mathrm{CDCl}_{3}\right.$, ppm) $\delta 8.14(\mathrm{~d}, J=8.2 \mathrm{~Hz}, 1 \mathrm{H}), 8.11(\mathrm{~s}, 1 \mathrm{H}), 7.76(\mathrm{~d}, J=7.97 \mathrm{~Hz}, 1 \mathrm{H}), 7.56(\mathrm{~d}, J=7.97 \mathrm{~Hz}, 1 \mathrm{H})$, 7.26-7.23 (m, 4H), 7.09-7.08 (m, 5H), 7.06-7.03 (m, 3H), $5.51(\mathrm{~s}, 1 \mathrm{H}), 2.95(\mathrm{~s}, 6 \mathrm{H}), 2.73$ (t, J = 7.97 
$\mathrm{Hz}, 4 \mathrm{H})$, and $2.32-2.18(\mathrm{~m}, 4 \mathrm{H}) ;{ }^{13} \mathrm{C}-\mathrm{NMR}\left(\mathrm{CDCl}_{3}\right) \delta 167.64\left[-\mathrm{C}=\mathrm{C}(\mathrm{CN})_{2}\right], 151.83$ (aminoaryl carbon), 150.31 (aminoaryl carbon), 149.45 (aminoaryl carbon), 147.23 (2C), 147.06 (2C), 146.07 (C), 145.69 (2C), 145.25 (4C), 145.21 (2C), 145.18 (2C), 145.15 (2C), 145.03 (2C), 144.72 (4C), 144.68 (4C), 144.53 (2C), 144.40 (2C), 144.15 (C), 143.69 (2C), 143.62 (2C), 142.94 (2C), 142.89 (4C), 142.36 (2C), 141.96 (2C), 141.94 (2C), 141.83 (2C), 141.36 (2C), 140.97 (2C), 137.31 (2C), 136.95 (2C), 132.12, 129.36, 128.46, 124.76, 123.63, 122.89, 122.39, 121.89, 119.67, 117.47, $112.99(-\mathrm{C} \equiv \mathrm{N})$, 112.92, 88.07 $\left[=\mathrm{C}(\mathrm{CN})_{2}\right], 72.30$ (fullerenyl $\mathrm{sp}^{3}$ carbons), 68.33, 58.26, 51.56, 41.22 (cyclopropanyl $\mathrm{C}_{60}>$ carbon), and 39.26. A total of 30 carbon peaks representing 58 fullerenyl $\mathrm{sp}^{2}$ carbons at $\delta 136-148$ indicated a $C_{2}$-symmetry of the fullerene cage.

3.3.7. Synthesis of Hybrid [(9,9-Dioctadecyl-2-diphenylaminofluorenyl)-7-carbonyl]-\{[9,9-(2dimethoxyethyl)-2-diphenylaminofluorenyl]-7-(1,1-dicyanoethylenyl)\}-bis(1,2-dihydro-1,2-methano)[60]fullerenyl Triad $\mathrm{C}_{60}\left(>\right.$ DPAF $\left.\mathrm{C}_{18}\right)\left(>\mathrm{CPAF} \mathrm{C}_{2 \mathrm{M}}\right)(3)$ and its Tetrad Analogous $\mathrm{C}_{60}(>$ DPAF-C 18$)$ $\left(>\mathrm{CPAF}-\mathrm{C}_{2 \mathrm{M}}\right)_{2}(\mathbf{4})$

To the mixture of 7-(1,2-dihydro-1,2-methano[60]fullerene-61-carbonyl)-9,9-di(octadecyl)-2diphenylaminofluorene $\quad \mathrm{C}_{60}\left(>\mathrm{DPAF}_{18}\right) \quad \mathbf{1}(0.48 \quad \mathrm{~g}, \quad 0.3 \mathrm{mmol})$ and 7-[2-bromo-1-(1,1dicyanoethylenyl)-1-methyl]-9,9-di(2-methoxyethyl)-2-diphenylaminofluorene $\left(\mathrm{BrCPAF}_{2 \mathrm{M}}, \mathbf{9}, 0.37\right.$ $\mathrm{g}, 0.6 \mathrm{mmol})$ in dry toluene $(100 \mathrm{~mL})$ was added 1,8-diazabicyclo[5,4,0]-undec-7-ene (DBU, $0.1 \mathrm{M}$, $6.0 \mathrm{~mL}$ ) slowly under a nitrogen atmosphere. After stirring at room temperature for a period of $5.0 \mathrm{~h}$, the reaction mixture was concentrated to a volume of approximately $10 \mathrm{~mL}$. Crude product was precipitated by the addition of methanol and isolated by centrifugation ( $8000 \mathrm{rpm}, 20 \mathrm{~min}$ ). The isolated solid was found to be a mixture of the fullerene multiadducts. Separation of these mixture was made by column chromatography (silica gel) using a solvent mixture of toluene-ethyl acetate (9:1) as the eluent. The first chromatographic band gave the unreacted starting compound 1 ( $0.08 \mathrm{~g}, 0.05 \mathrm{mmol})$. The second chromatographic band corresponding to $R_{\mathrm{f}}=0.5$ on the thin-layer chromatographic plate [TLC, $\mathrm{SiO}_{2}$, toluene-ethyl acetate $(9: 1)$ as the eluent] afforded the bisadduct product $\mathrm{C}_{60}$ (>DPAF$\left.\mathrm{C}_{18}\right)(>$ CPAF-C $2 \mathrm{M}) 3$ as orange-brown solids $(0.15 \mathrm{~g}, 0.07 \mathrm{mmol})$ in a $28 \%$ yield [based on the recovered $\mathrm{C}_{60}\left(>\right.$ DPAF-C 18 ) amount]. The third chromatographic band corresponding to $R_{\mathrm{f}}=0.4$ on the thin-layer chromatographic plate [TLC, $\mathrm{SiO}_{2}$, toluene-ethyl acetate (4:1) as the eluent] afforded the trisadduct product $\mathrm{C}_{60}\left(>\mathrm{DPAF}-\mathrm{C}_{18}\right)\left(>\mathrm{CPAF}-\mathrm{C}_{2 \mathrm{M}}\right)_{2} \mathbf{4}$ as red-brown solids $(0.28 \mathrm{~g}, 0.10 \mathrm{mmol})$ in a yield of $40 \%$ [based on the recovered $\mathrm{C}_{60}\left(>\mathrm{DPAF}-\mathrm{C}_{18}\right)$ amount]. Spectroscopic data of $\mathrm{C}_{60}\left(>\mathrm{DPAF}-\mathrm{C}_{18}\right)$ $\left(>\right.$ CPAF-C $\left._{2 \mathrm{M}}\right)$ 3: FT-IR (KBr) $v_{\max }$ 3,424 (w), 3,063 (w), 3,030 (w), 2,921 (m), 2,850 (m), 2,223 (m), 1,678 (m), 1,593 (s), 1,568 (m), 1,537 (w), 1,492 (m), 1,465 (m), 1,426 (m), 1,346 (m), 1,277 (s), 1,202 (m), 1,115 (m), 1,074 (w), $962(\mathrm{w}), 895(\mathrm{w}), 819(\mathrm{~m}), 753(\mathrm{~s}), 696(\mathrm{~s}), 578(\mathrm{w}), 526(\mathrm{~m})$, and 491 (w) $\mathrm{cm}^{-1}$; MALDI-MS (TOF) $\mathrm{m} / \mathrm{z} 2,135$ calculated for ${ }^{12} \mathrm{C}_{159}{ }^{1} \mathrm{H}_{122}{ }^{14} \mathrm{~N}_{4}{ }^{16} \mathrm{O}_{3}$; found, $\mathrm{m} / \mathrm{z} 2,136$ $\left(\mathrm{MH}^{+}\right), 2,135\left(\mathrm{M}^{+}\right), 965,920,866,763\left\{\mathrm{C}_{60}[>(\mathrm{C}=\mathrm{O})-\mathrm{H}] \mathrm{H}^{+}\right\}, 735\left(\mathrm{C}_{60}>\mathrm{H}^{+}\right)$, and $720\left(\mathrm{C}_{60}{ }^{+}\right)$; UV-vis $\left(\mathrm{CHCl}_{3}\right) \lambda_{\max }(\varepsilon) 255\left(1.1 \times 10^{5}\right), 304\left(7.5 \times 10^{4}\right), 413\left(3.9 \times 10^{4}\right)$, and $494 \mathrm{~nm}\left(2.3 \times 10^{4} \mathrm{~L} / \mathrm{mol}-\mathrm{cm}\right)$; ${ }^{1} \mathrm{H}-\mathrm{NMR}\left(\mathrm{CDCl}_{3}, \mathrm{ppm}\right) \delta 8.51-7.52(\mathrm{~m}, 8 \mathrm{H}), 7.28-7.22(\mathrm{~m}, 8 \mathrm{H}), 7.14-7.00(\mathrm{~m}, 16 \mathrm{H}), 5.76-5.18(\mathrm{~m}$, 2H), 3.01-2.90 (br, 6H), 2.82-2.67 (br, 4H), 2.40-2.14 (br, 4H), 2.06-1.80 (br, 4H), 1.31-1.04 (m, $58 \mathrm{H}), 0.87(\mathrm{t}, J=6.72 \mathrm{~Hz}, 6 \mathrm{H})$, and $0.67(\mathrm{br}, 4 \mathrm{H})$. Spectroscopic data of $\mathrm{C}_{60}\left(>\mathrm{DPAF} \mathrm{C}_{18}\right)\left(>\mathrm{CPAF}-\mathrm{C}_{2 \mathrm{M}}\right)_{2}$ 4: FT-IR (KBr) $v_{\max }$ 3,433 (m), 3,060 (w), 3,027 (w), 2,922 (m), 2,851 (m), 2,224 (m), 1,679 (w), 
1,594 (s), 1,539 (w), 1,492 (s), 1,466 (m), 1,426 (m), 1,346 (m), 1,331 (w), 1,279 (s), 1,207 (w), 1,115 (m), $1028(\mathrm{w}), 958(\mathrm{w}), 892(\mathrm{w}), 818(\mathrm{~m}), 753(\mathrm{~m}), 697(\mathrm{~m}), 616(\mathrm{w})$, and $525(\mathrm{w}) \mathrm{cm}^{-1}$; MALDI-MS (TOF) $m / z, 2,672$ calculated for ${ }^{12} \mathrm{C}_{195}{ }^{1} \mathrm{H}_{153}{ }^{14} \mathrm{~N}_{7}{ }^{16} \mathrm{O}_{5}$; found, $m / z, 2,673\left(\mathrm{MH}^{+}\right), 2,672\left(\mathrm{M}^{+}\right), 965,920$, 866, $763\left\{\mathrm{C}_{60}[>(\mathrm{C}=\mathrm{O})-\mathrm{H}] \mathrm{H}^{+}\right\}, 735\left(\mathrm{C}_{60}>\mathrm{H}^{+}\right)$, and $720\left(\mathrm{C}_{60}{ }^{+}\right)$; UV-vis $\left(\mathrm{CHCl}_{3}\right) \lambda_{\max }(\varepsilon) 304\left(1.1 \times 10^{5}\right)$, $417\left(4.6 \times 10^{4}\right)$, and $500 \mathrm{~nm}\left(4.6 \times 10^{4} \mathrm{~L} / \mathrm{mol}-\mathrm{cm}\right) ;{ }^{1} \mathrm{H}-\mathrm{NMR}\left(\mathrm{CDCl}_{3}, \mathrm{ppm}\right) \delta 8.44-7.46(\mathrm{~m}, 16 \mathrm{H})$, 7.09-7.03 (br, 32H), 5.57-4.72 (m, 3H), 3.08-2.86 (br, 12H), 2.73 (br, 8H), 2.21 (br, 8H), 1.91 (br, $4 \mathrm{H}), 1.3-0.95(\mathrm{~m}, 58 \mathrm{H}), 0.86(\mathrm{t}, J=6.55 \mathrm{~Hz}, 6 \mathrm{H})$, and $0.64(\mathrm{br}, 4 \mathrm{H})$.

\section{Conclusions}

Two new $\mathrm{C}_{60}$-(antenna) $)_{\mathrm{x}}$ analogous compounds as branched triad $\mathrm{C}_{60}\left(>\mathrm{DPAF} \mathrm{C}_{18}\right)\left(>\mathrm{CPAF}-\mathrm{C}_{2 \mathrm{M}}\right)$ and tetrad $\mathrm{C}_{60}\left(>\mathrm{DPAF}-\mathrm{C}_{18}\right)\left(>\mathrm{CPAF}-\mathrm{C}_{2 \mathrm{M}}\right)_{2}$ nanostructures were synthesized and characterized by various spectroscopic methods. The design of 2PA-responsive chromophores was made by covalently attaching multiple light-harvesting donor antenna units on a $\mathrm{C}_{60}$ (acceptor) via a periconjugation linkage within a separation distance of 2.6-3.5 $\AA$. This structural design was intended to facilitate the ultrafast femtosecond intramolecular energy-transfer process from the photoexcited $\mathrm{C}_{60}\left[>^{1}(\mathrm{DPAF})^{*}\right.$ $\left.\mathrm{C}_{18}\right]\left(>\mathrm{CPAF}-\mathrm{C}_{2 \mathrm{M}}\right)_{1 \text { or } 2}$ or $\mathrm{C}_{60}\left(>\mathrm{DPAF}-\mathrm{C}_{18}\right)\left[>^{1}(\mathrm{CPAF})^{*}-\mathrm{C}_{2 \mathrm{M}}\right]_{1 \text { or } 2}$ to the $\mathrm{C}_{60}$ cage moiety upon two-photon pumping at either 780 or $980 \mathrm{~nm}$, respectively. Interestingly, by adjustment of a higher number of $\mathrm{CPAF}_{2 \mathrm{M}}$ antenna, the resulting tetrads showed nearly equal absorption in extinction coefficients over the wavelength range of $400-550 \mathrm{~nm}$ that corresponds to near-IR two-photon based excitation wavelengths at $780-1,100 \mathrm{~nm}$ for broadband $2 \gamma$-PDT applications. We also found that the unique feature of intramolecular Förster energy-transfer phenomena from the photoexcited high-energy DPAF- $\mathrm{C}_{18}$ antenna unit to the low-energy $\mathrm{CPAF}-\mathrm{C}_{2 \mathrm{M}}$ moiety at the fullerene cage surface gave the fluorescence emission at slightly longer wavelengths than $600 \mathrm{~nm}$ in a cascade fashion. It may be correlated to and provide an interesting mechanism for the enhancement of $2 \mathrm{PA}$ cross-section values of these hybrid $\mathrm{C}_{60}-(\text { antenna })_{\mathrm{x}}$ nanostructures.

\section{Supplementary Materials}

Supplementary materials can be accessed at: http://www.mdpi.com/1420-3049/18/8/9603/s1.

\section{Acknowledgements}

The authors at UML thank the financial support of Air Force Office of Scientific Research (AFOSR) under the grant number FA9550-09-1-0380 and FA9550-09-1-0183 and National Institute of Health (NIH) under the grant number 4R01CA137108. MR Hamblin was supported by NIH R01AI058075.

\section{Conflict of Interest}

The authors declare no conflict of interest.

\section{References}

1. Guldi, D.M.; Prato, M. Excited-state properties of $\mathrm{C}_{60}$ fullerene derivatives. Acc. Chem. Res. 2000, 33, 695-703. 
2. Fujitsuka, M.; Ito, O. Encyclopedia of Nanoscience and Nanotechnology; Nalwa, H.S., Ed.; American Scientific Pub.: Valencia, CA, USA, 2004; Volume 8, pp. 593-615.

3. Bhawalkar, J.D.; Kumar, N.D.; Zhao, C.-F.; Prasad, P.N. Two-photon photodynamic therapy. J. Clin. Laser Med. Surg. 1997, 15, 201-204.

4. Brown, S. Photodynamic Therapy: Two photons are better than one. Nat. Photonics 2008, 2, 394-395.

5. Spangler, C.W.; Starkey, J.R.; Dubinina, G.; Fahlstromb, C.; Shepard, J. Optimization of targeted two-photon PDT triads for the treatment of head and neck cancers. Proc. SPIE 2012, 8207, 820720.

6. Spangler, C.W.; Starkey, J.; Rebane, A.; Drobizhev, M.; Meng, F.; Gong, A. Synthesis, characterization and two-photon PDT efficacy studies of triads incorporating tumor targeting and imaging components. Proc. SPIE 2008, 6845, 68450S.

7. Dahlstedt, Z.E.; Collins, H.A.; Balaz, M.; Kuimova, M.K.; Khurana, M.; Wilson, B.C.; Phillips, D.; Anderson, H.L. One- and two-photon activated phototoxicity of conjugated porphyrin dimers with high two-photon absorption cross sections. Org. Biomol. Chem. 2009, 7, 897-904.

8. Riggs, J.E.; Sun, Y.-P. Optical limiting properties of [60]fullerene and methano[60]fullerene in solution versus in polymer matrix: the role of bimolecular processes and a consistent nonlinear absorption mechanism. J. Phys. Chem. A 1999, 103, 485-495.

9. Maggini, M.; Faveri, C.D.; Scorrano, G.; Prato, M.; Brusatin, G.; Guglielmi, M.; Meneghetti, M.; Signorini, R.; Bozio, R. Synthesis and optical-limiting behavior of hybrid inorganic-organic materials from the sol-gel processing of organofullerenes. Chem. Eur. J. 1999, 5, 2501-2510.

10. Chiang, L.Y.; Padmawar, P.A.; Canteewala, T.; Tan, L.-S.; He, G.S.; Kanna, R.; Vaia, R.; Lin, T.-C.; Zheng, Q.; Prasad, P.N. Synthesis of $\mathrm{C}_{60}$-diphenylaminofluorene dyad with large 2PA cross-sections and efficient intramolecular two-photon energy transfer. Chem. Commun. 2002, 1854-1855.

11. Koudoumas, E.; Konstantaki, M.; Mavromanolakis, A.; Couris, S.; Fanti, M.; Zerbetto, F.; Kordatos, K.; Prato, M. Large enhancement of the nonlinear optical response of reduced fullerene derivatives. Chem. Eur. J. 2003, 9, 1529-1534.

12. Padmawar, P.A.; Canteenwala, T.; Verma, S.; Tan, L.-S.; Chiang, L.Y. Synthesis and photophysical properties of $\mathrm{C}_{60}$-diphenylaminofluorene dyad and multiads. J. Macromol. Sci. A Pure Appl. Chem. 2004, 41, 1387-1400.

13. Padmawar, P.A.; Canteenwala, T.; Tan, L.-S.; Chiang, L.Y. Synthesis and characaterization of two-photon absorbing diphenylaminofluorenocarbonyl-methano[60]fullerenes. J. Mater. Chem. 2006, 16, 1366-1378.

14. Padmawar, P.A.; Rogers, J.O.; He, G.S.; Chiang, L.Y.; Canteenwala, T.; Tan, L.-S.; Zheng, Q.; Lu, C.; Slagle, J.E.; Danilov, E.; et al. Large cross-section enhancement and intramolecular energy transfer upon multiphoton absorption of hindered diphenylaminofluorene- $\mathrm{C}_{60}$ dyads and triads. Chem. Mater. 2006, 18, 4065-4074.

15. Kopitkovas, G.; Chugreev, A.; Nierengarten, J.F.; Rio, Y.; Rehspringer, J.L.; Honerlage, B. Reverse saturable absorption of fullerodendrimers in porous $\mathrm{SiO}_{2}$ sol-gel matrices. Opt. Mater. 2004, 27, 285-291.

16. He, G.S.; Tan, L.-S.; Zheng, Q.; Prasad, P.N. Multiphoton absorbing materials: molecular designs, characterizations, and applications. Chem. Rev. 2008, 108, 1245-1330.

17. Spangler, C.W. Recent development in the design of organic materials for optical power limiting. J. Mater. Chem. 1999, 9, 2013-2020. 
18. Mckay, T.J.; Staromlynska, J.; Wilson, P.; Davy, J. Nonlinear luminescence in a Pt: ethynyl compound. J. Appl. Phys. 1999, 85, 1337-1341.

19. Perry, J.W. Nonlinear Optics of Organic Molecules and Polymers; Nalwa, H.S., Miyata, S., Eds.; CRC Press: Boca Raton, FL, USA, 1997; pp. 813-840.

20. MacMahon, S.; Fong II, R.; Baran, P.S.; Safonov, I.; Wilson, S.R.; Schuster, D.I. Synthetic approaches to a variety of covalently linked porphyrin-fullerene hybrids. J. Org. Chem. 2001, 66, 5449-5455.

21. Li, K.; Schuster, D.I.; Guldi, D.M.; Herranz, M.A.; Echegoyen, L. Convergent synthesis and photophysics of [60]fullerene/porphyrin-based rotaxanes. J. Am. Chem. Soc. 2004, 126, 3388-3389.

22. Huang, Y.Y.; Sharma, S.K.; Dai, T.; Chung, H.; Yaroslavsky, A.; Garcia-Diaz, M.; Chang, J.; Chiang, L.Y.; Hamblin, M.R. Can nanotechnology potentiate photodynamic therapy? Nanotechnol. Rev. 2012, 1, 111-146.

23. Sperandio, F.F.; Gupta, A.; Wang, M.; Chandran, R.; Sadasivam, M.; Huang, Y.-Y.; Chiang, L.Y.; Hamblin, M.R. Photodynamic Therapy Mediated by Fullerenes and Their Derivatives; ASME Press: New York, NY, USA, 2013; Biomed. Nanomed. Technol. (B\&NT): Concise Monographs Series, pp. 1-51.

24. Elim, H.I.; Jeon, S.-H.; Verma, S.; Ji, W.; Tan, L.-S.; Urbas, A.; Chiang, L.Y. Nonlinear optical transmission properties of $\mathrm{C}_{60}$ dyads consisting of a light-harvesting diphenylaminofluorene antenna. J. Phys. Chem. B 2008, 112, 9561-9564.

25. Chiang, L.Y.; Padmawar, P.A.; Rogers-Haley, J.E.; So, G.; Canteenwala, T.; Thota, S.; Tan, L.-S.; Pritzker, K.; Huang, Y.-Y.; Sharma, S.K.; et al. Synthesis and characterization of highly photoresponsive fullerenyl dyads with a close chromophore antenna- $\mathrm{C}_{60}$ contact and effective photodynamic potential. J. Mater. Chem. 2010, 20, 5280-5293.

26. Elim, H.I.; Anandakathir, R.; Jakubiak, R.; Chiang, L.Y.; Ji, W.; Tan, L.S. Large concentrationdependent nonlinear optical responses of starburst diphenylaminofluorenocarbonyl methano[60]fullerene pentaads. J. Mater. Chem. 2007, 17, 1826-1838.

27. El-Khouly, M.E.; Padmawar, P.; Araki, Y.; Verma, S.; Chiang, L.Y.; Ito, O. Photoinduced processes in a tricomponent molecule consisting of diphenylaminofluorene-dicyanoethylenemethano[60]fullerene. J. Phys. Chem. A 2006, 110, 884-891.

28. Luo, H.; Fujitsuka, M.; Araki, Y.; Ito, O.; Padmawar, P.; Chiang, L.Y. Inter- and intramolecular photoinduced electron-transfer processes between $\mathrm{C}_{60}$ and diphenylaminofluorene in solutions. J. Phys. Chem. B 2003, 107, 9312-9318.

29. Saito, S.; Oshiyama, A. Cohesive mechanism and energy bands of solid $\mathrm{C}_{60}$. Phys. Rev. Lett. 1991, 66, 2637-2640.

Sample Availability: Samples of the compounds $\mathbf{3}$ and $\mathbf{4}$ are available from the authors upon request and conditions.

(C) 2013 by the authors; licensee MDPI, Basel, Switzerland. This article is an open access article distributed under the terms and conditions of the Creative Commons Attribution license (http://creativecommons.org/licenses/by/3.0/). 